VERTAISARVIOITU

KOLLEGIALT GRANSKAD

PEER-REVIEWED

www.tsv.fi/tunnus

(c) (7)

Sami Pekola

\title{
Länsirajan rakentaminen ja ylittäminen vuodesta 1809
}

\begin{abstract}
ABSTRAKTI / ABSTRACT
Artik.kelissa tarkastellaan, miten vuodesta 1809 läbtien Suomen ja Ruotsin välistä pobjoista maarajaa rakennettiin etenkin oikeudellisesti aiemmin jakamattomalle alueelle. Lisäksi selvitetään, miten elämä jatkui undesta rajasta buolimatta ja sen yli, toisinaan ristiriidassa valtiollisten pyrkimysten kanssa. Tarkastelu painottun vilkkeaista rajan ylittävistä yhteyksistään tunnetun Tornionlaakson eteläosiin, erityisesti Tornion ja Haaparannan alueeseen. Jäsentämällä ja yhdistämällä olemassa olevaa tutkimusta sekä oikeudellista lähdeaineistoa kuvataan temaattisesti pohjoisen länsirajan rakentamisen kehityskaari Suomen autonomian ajalla. Monilta osin ajanjaksolla luotiin perusta myös nykyisille pohjoisen länsirajan oloille. Rajan historia on osoitus siitä, miten tilannesidonnaisesta ja paikallisväestöstä rïppumattomasta rajan vetämisestä voi ajan myötä seurata kanaskantoisia ja alueen ibmisiin vaikuttavia seuranksia. Vaikeka raja on aluksi vain sopimustekstiä, se konkretisoidaan toiminnalla. Raja ei synny vaan rakentuu. Pobjoisen rajaseudun paikalliseen elämänmuotoon kunluva rajattomun ja sen osittainen huomiointi myös valtioiden välisissä subteissa tuo aiheeseen mielenkiintoista ristiriitaisuntta.
\end{abstract}

raja, pohjoinen, autonomian aika

OTM, VTM, FM Sami Pekola, Lapin yliopisto, oikeustieteiden tiedekunta, spekola@ulapland.fi 


\section{Johdanto}

\section{"Ei Jumala antanut meille rajaa, ja laitkin ovat ihmisten tekemiä."}

Vuonna 2020 alkaneen koronakriisin rajoitustoimenpiteet vähensivät länsirajan avoimuutta ja aiheuttivat ongelmia pohjoisella rajaseudulla. ${ }^{2}$ Jo melkein unohdettu valtakunnanraja oli sitenkin voimissaan ja moni ymmällään. Länsirajan nykysääntely ja -käytännöt ovat osa yleistä historiallista muutosta, jonka kehityskaari on tärkeää tuntea. Näin voimme ymmärtää nykyisyyttä ja myös saada tietoa raja-alueiden oikeudelliseen ja hallinnolliseen kehittämiseen. ${ }^{3}$

Hans-Georg Gadamerin mukaan olemme sisällä historiassa ja jokaisen nykyisyyden on kirjoitettava historia uudelleen. ${ }^{4}$ Kylmän sodan jälkeisessä rajatutkimuksessa näytti usein vallinneen käsitys Euroopan rauhasta ja vakaudesta, geopolitiikan merkityksen kutistumisesta sekä länsi-integraation voittokulusta. Nyt tuosta vaiheesta on siirrytty johonkin uuteen, jossa myös valtioiden rajat ja niiden historia näyttäytyvät toisenlaisina.

Suomen ja Ruotsin liittyminen Euroopan unionin jäseniksi vähensi osaltaan kiinnostusta pohjoismaiseen yhteistyöhön. Sitä ei nähty silloisessa tilanteessa kovin tarpeellisena. ${ }^{5}$ Viime vuosien tapahtumien myötä Pohjoismaista on arvioiden mukaan tullut jälleen aiempaa tärkeämpi viiteryhmä niin Suomelle kuin Ruotsille. ${ }^{6}$ Myös tämä vaikuttaa siihen, miten pohjoisia rajoja tarkastellaan.

Uudessa tilanteessa on tärkeää tuntea, miten Suomen ja Ruotsin välinen raja on muodostunut. Vaikka raja on nykyään kahden itsenäisen valtion välinen, sen perusta valettiin Suomen autonomian ajalla. Kirjoituksessa tarkastellaan, miten Suomen ja Ruotsin välinen pohjoinen maaraja sai alkunsa ja miten rajaa rakennettiin etenkin valtiollisin ja oikeudellisin keinoin alueelle, joka aiemmin oli ollut jakamaton. Toisaalta tarkastellaan, miten elämä jatkui uudesta rajasta huolimatta ja sen ylittäen, toisinaan valtiollisten pyrkimysten kanssa erisuuntaisesti.

Vaikka autonomian aikaa ja pohjoista raja-aluetta on tutkittu laajasti, historian tapahtumakirjosta löytyy aina tilaa uusille tulkinnoille. ${ }^{7}$ Artikkelissa jäsennetään ja yhdistetään olemassa olevaa tutkimusta sekä oikeudellista lähdeaineistoa pohjoisen rajaseudun kehityskaaren hahmottamiseksi. Tarkastelu painottuu maantieteellisesti Tornionlaakson ${ }^{8}$ eteläosiin, erityisesti Tornion ja Haaparannan alueeseen, jossa rajan ylittävä toiminta on ollut monimuotoista ja runsasta. ${ }^{9}$ Pohjoisempien alueiden tärkeitä kehityskulkuja ovat tutkineet muun muassa Maria Lähteenmäki ja Matti Enbuske. ${ }^{10}$

Tarkastelun ajallinen alkupiste on vuosi 1809, jolloin Tornionlaaksoa alkoi halkoa valtakunnanraja. Rajalinja määrittyi sotimisen jälkeisenä tilannesidonnaisena poliittisena kompromissina, mikä on valtioiden rajojen tyypillinen muodostumistapa. ${ }^{11}$ Vaikka rajoja helposti pidetään pysyvinä, ovat ne ja niiden sisältämät alueelliset yksiköt historian tuotosta ja muutoksen tilassa: niitä on lähestyttävä historian kuluessa muovautuneina rakennelmina. Myös Suomen valtioalue muodostettiin ulkoisten poliittisten voimien vaikutuksesta, ei sisäsyntyisesti. ${ }^{12}$

Oikeudellispoliittisen rajanvedon lisäksi vuosi 1809 tuli merkitsemään alkupistettä Tornionlaakson itä- ja länsipuolten erilaistumiskehitykselle, vaikka Suomen ja Ruotsin muotoutuminen integroituneiksi nykyaikaisiksi kansallisvaltioiksi oli vielä kaukana. ${ }^{13}$ Länsirajan historiaa on tarkasteltava silloisista olosuhteista ja lähtökohdista käsin, ei kansallisvaltiollisen jatkuvuuden laput silmillä. Näin voidaan paremmin ymmärtää, miten raja on muovautunut sosiaalisena konstruktiona, jolla on merkittäviä vaikutuksia alueen ihmisten elämään. ${ }^{14}$ 
Raja ei kuitenkaan tarkoittanut täyttä epäjatkuvuutta ja ylittämätöntä estettä. Päinvastoin monet yhteisestä historiallisesta perinnöstä juontuvat tekijät loivat Ruotsin valtakunnan hajoamisen jälkeen edellytyksiä yhteiskunnalliselle jatkuvuudelle, vaikka myös uusia toimintamalleja oli luotava. Suomen ja Ruotsin erilainen kehitys, jonka juuret ovat yhteisessä historiassa, luo erinomaiset edellytykset tarkastella sitä, miten ihmisten, yhteisöjen ja valtioiden väliset suhteet muodostuvat. ${ }^{17}$ Tähän voidaan saada tietoa pohjoisen rajaseudun historiasta.

Vaikka kansallisvaltiollisuus tuntuu ilmiselvältä, historiallisesti ylirajainen Lappi on vanhempi ihmisten välinen vuorovaikutusalue kuin Suomen, Ruotsin tai Norjan valtiot rajoineen. ${ }^{18}$ Tuoreehkot pohjoiset valtionrajat voidaan mieltää alueen kolonisaatioon ja valtiosuvereniteetin vahvistamiseen liittyvinä ilmiöinä. Ihmisyhteisöjen on täytynyt mukautua valtioiden yhteiskunnallisiin ja oikeudellisiin järjestelmiin. ${ }^{19}$

Kirjoituksen rakenne on temaattinen. Aluksi tarkastellaan, miten pohjoiseen länsirajaan päädyttiin ja miten se muutti alueen olosuhteita sekä tehdään katsaus siihen, miten rajasta pyrittiin tekemään myös ihmisiä erotteleva. Tämän jälkeen selvitetään, miten omistussuhteet, liikkuminen, liikenne- ja viestintäyhteydet, rajavalvonta ja kaupallinen toiminta järjestettiin sekä millaista oli valtiollisen rajasääntelyn ulkopuolinen rajan ylittävä toiminta. Tarkastelu päättyy rajaolojen tiukentumisen erittelyn kautta Suomen itsenäistymiseen. Lopuksi esitetään johtopäätökset pohdintoineen.

\section{Tornionlaakso kahtia vuonna 1809}

\section{Kompromissi rajalinjasta}

Englannin mannermaansulkuun tähdännyt sota Ruotsin ja Venäjän välillä päättyi Haminan rauhaan syyskuussa $1809 .{ }^{20}$ Sodankäynnin tuloksena Suomi siirtyi osaksi Venäjän keisarikuntaa. Uusi raja näkyi konkreettisimmin Torniossa ja Tornionlaaksossa, jota joet olivat kautta aikain yhdistäneet. ${ }^{21}$ Nyt jokia pitkin kulki yli 500 kilometriä pitkä valtionraja. ${ }^{22}$ Rauhansopimuksen 5 artiklan nojalla raja kulki tietyin poikkeuksin syväväylän ${ }^{23}$ mukaisesti:

"Tornionjoen suulla Pirkkeiön saari, Röyttän satama ja se niemi, jolla Tornion kaupunki sijaitsee, ovat venäläisten omistusten uloimpia kohtia. Raja jatkun pitkin Tornionjokea sïhen kobtaan, missä joen kaksi haaraa yhtyvät Kengisin (Könkäsen) runkin luona, ja seuraa sieltä Muonionjoen väylää....". ${ }^{24}$ 


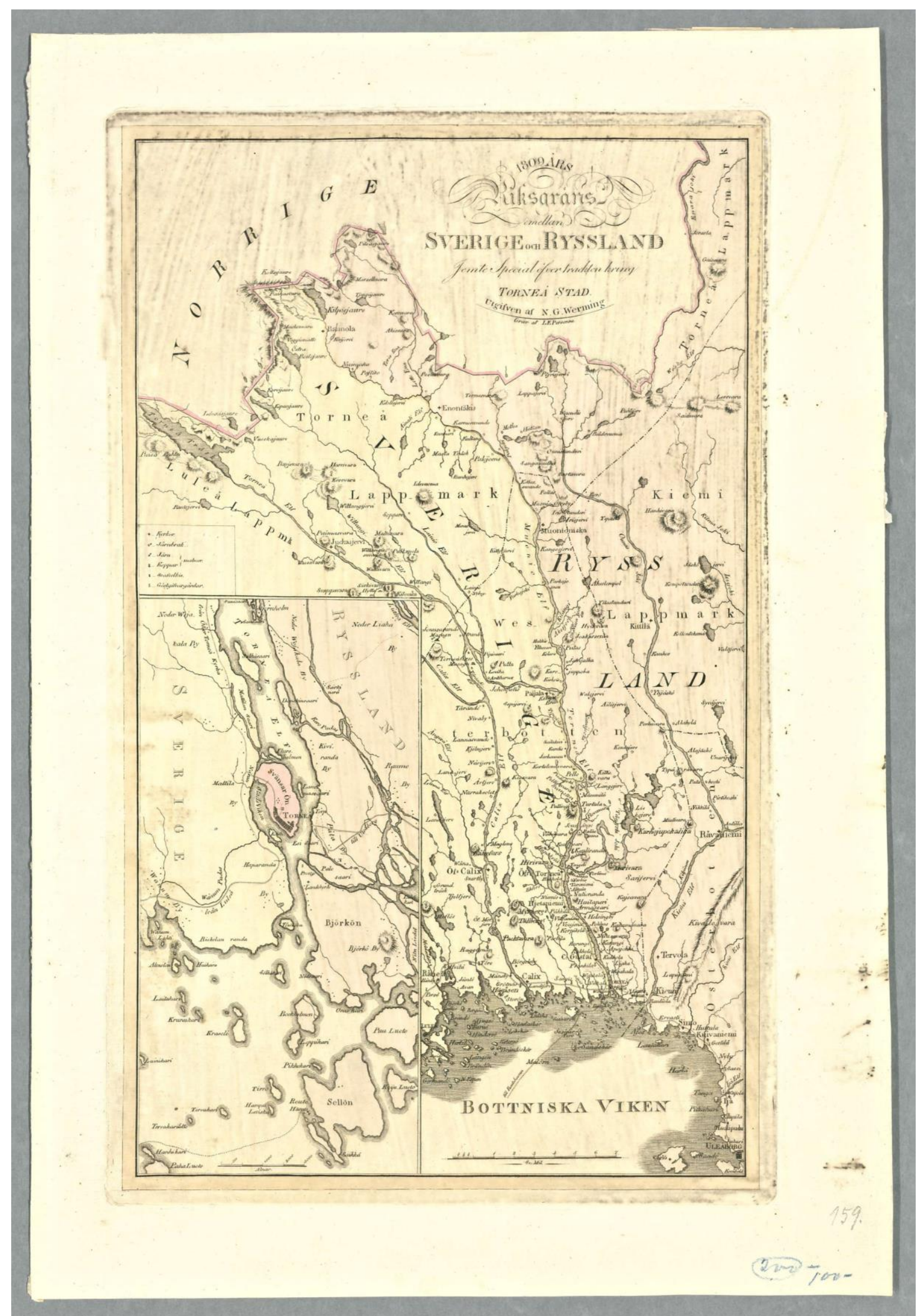

Kuva 1. Vuoden 1809 raja pohjoisessa. Kansalliskirjasto 
Tornionlaakso oli ollut Ruotsin valtakunnan merkittävä kauppa-alue vuosisatoja ja Tornio saanut kaupunkioikeudet vuonna 1621. Kauppa-alue ulottui laajalle Kemin ja Tornion Lappiin. ${ }^{25}$ Suomen alueen joutuminen osaksi Venäjää oli pitkän kehityksen tulosta, jossa vaikuttivat niin Ruotsin valtakunnan heikkeneminen, Venäjän strategiset tavoitteet kuin Euroopan suurpoliittinen tilanne. Venäjän sotavoimat olivat olleet nykyisen Suomen alueella useamman kerran jo 1700-luvulla, myös Torniossa asti. Pysyvästi Venäjä ei vallannut alueita lukuun ottamatta rajan siirtämisiä kaakossa 1721 ja $1743 .{ }^{26}$ Myöskään helmikuussa 1808 alkaneessa sodassa alkuperäinen tavoite ei ollut Suomen lopullinen irrottaminen Ruotsista. Poliittinen tarve alueen liittämiseksi Venäjän valtakuntaan syntyi ensi sijassa muiden Napoleonin ajan sotien Venäjälle epäedullisten tapahtumien vuoksi. ${ }^{27}$

Rajan lopullinen linja määrittyi neuvotteluissa. Venäläiset vaativat rajaa Kalixjoelle, joka oli käytännössä armeijoiden välinen demarkaatiolinja. Se oli myös suurin piirtein jo keskiajalla muodostunut ruotsin- ja suomenkielisen väestön välinen linja. Ruotsalaiset pyrkivät saamaan venäläiset taipumaan Kemijokea pitkin menevään rajaan, perusteena vanhan Västerbottenin läänin alueet. Kumpikaan ei omista sotilaspoliittisista syistään halunnut venyttää asian ratkaisemista ja päädyttiin välimaastoon: TornionjoenMuonionjoen -linjaan. Sillä ei aikaisemmin ollut ollut merkitystä alue- tai paikallishallinnollisena rajana. Raja teki mutkan Tornion kohdalla siten, että Venäjä sai tämän tärkeän pohjoisen kauppapaikan itselleen. Ruotsi perusti rajan länsipuolelle Karl Johanin kaupungin, myöhemmin Haaparannan. ${ }^{28}$ Rajankulkua täsmennettiin syksyllä 1810 rajanjärjestelysopimuksella. ${ }^{29}$

Ruotsin kuningas Kustaa IV Aadolf sai väistyä vuonna 1809. Maa luopui pian suurvalta-asemansa palauttamishaaveista ja lakkasi havittelemasta Suomea takaisin. Palkinnoksi Ruotsi sai Venäjän myötämielisyyden hankkia haltuunsa Norja, jonka alue sopi Suomea paremmin tuolloiseen luonnollisten rajojen teoriaan. Näin Pohjolan valtionrajat alkoivat muotoutua nykylinjoihinsa. ${ }^{30}$ Rajan myötä synnytettiin myös

7 Suomen alueeseen kuuluva Suomen Lappi. ${ }^{31}$ Sen alueellista ja hallinnollista kokonaisuutta rakennettiin Ruotsin vallan aikana luotujen instituutioiden, kuten seurakuntahallinnon sekä oikeus- ja verotuskäytännön pohjalle. ${ }^{32}$

Suomen pohjoiset alueet liitettiin hallinnollisesti Oulun lääniin muodostettuun Tornion kihlakuntaan, oikeudellisesti Vaasan hovioikeuden alaisuuteen ja kirkollisesti Turun Hiippakuntaan. Ruotsin alueet taas tulivat kuulumaan 1810 perustettuun Norrbottenin lääniïn. ${ }^{33}$ Tornionlaakson kylät repesivät kahtia. Rajan länsipuolelle jääneistä etnisistä suomalaisista tuli pieni vähemmistö Ruotsin valtakunnassa. Suomen ruotsinkielinen väestö, jota etenkin Torniossa oli paljon, puolestaan muuttui vähemmistökielen edustajiksi, vaikka ruotsi säilyikin pitkään ainoana virallisena kielenä. ${ }^{34}$ Suomea koskevat päätökset tehtiin Tukholman sijaan keisarikunnan ja suuriruhtinaskunnan pääkaupungeissa.$^{35}$ Länsirajaa tuli leimaamaan sääntelyllinen epäyhdenmukaisuus ja -tahtisuus, mikä vaikutti alueen käytännön elämään ja elinkeinotoimintaan.

Tornionlaakson alue kuului vuodesta 1809 lähtien kahden eri oikeusjärjestyksen ja -järjestelmän piiriin. ${ }^{36}$ Kansainvälisoikeudellisessa mielessä Venäjä peitti Suomen, jolla ei ollut omia ulkopoliittisia hallintoelimiä tai ulkopolitiikkaa. ${ }^{37}$ Suhteessa ulkovaltoihin Venäjä oli kokonaisuus, johon Suomi kuului huolimatta sisäisestä erikoisasemastaan. ${ }^{38}$ Ruotsin ja Suomen välisiä virallisia suhteita hoidettiin Venäjän ulkoministeriön kautta. Vain poikkeustapauksissa sallittiin suomalais- ja ruotsalaisviranomaisten pitävän kahdenvälisiä yhteyksiä toisiinsa. ${ }^{39}$ Pohjoisella rajaseudulla yhteydenpitoa kuitenkin käytännössä esiintyi.

Suomen siirto osaksi Venäjää ei tarkoittanut oikeudellista epäjatkuvuutta. Suuriruhtinaskunnassa säilyivät voimassa ja sovellettavina Ruotsin lait. Käytäntö tuli osoittamaan, että hallitseminen perustui etenkin vuoden 1772 hallitsijakeskeiseen kustavilaiseen hallitusmuotoon sekä vuoden 1789 yhdistys- ja vakuuskirjaan. ${ }^{40}$ Ratkaisu vastasi Venäjän aiempia aluevaltauksia, joissa keisari vahvisti alamaistensa enti- 
set lait ja oikeudet vastineeksi uskollisuudenvalasta. Vahvistaminen tapahtui kuitenkin vain yleisellä tasolla. Yksittäisten lakien kohdalla voimassaolon määrittely tehtiin vasta myöhemmässä hallintokäytännössä. ${ }^{41}$ Ratkaisu mahdollisti joustavan politiikan ja tapauskohtaisen laintulkinnan. ${ }^{42}$

Osmo Jussilan ja Keijo Korhosen mukaan keisari kunnioitti tuolloisen venäläisen laillisuuskäsityksen mukaisesti vapaaehtoisesti niin itse säätämiään kuin edeltäjiensä antamia lakeja ja muutti niitä vain vakiintuneita muotoja noudattaen, mutta ei ollut tähän minkään ulkopuolisen tekijän velvoittama - niin sanotun perustuslaillisen kannan edustajat ovat olleet asiasta eri mieltä. ${ }^{43}$ Käytännössä keisarit ottivat perustuslait lainsäädäntöasioissa vaihtelevasti huomioon. ${ }^{44}$ Ruotsi puolestaan uudisti valtiosääntönsä perustuslailliseksi monarkiaksi, mikä kavensi hallitsijan muodollista sekä tosiasiallista valtaa. Sensuurin jälleen lopettaminen ja painovapaus veivät nekin Ruotsia demokraattisempaan suuntaan. ${ }^{45}$ Ruotsin vapaammat lehdistöolot tulivat aiheuttamaan päänvaivaa rajan itäpuolen sensuuriviranomaisille.

Porvoon valtiopäivien/maapäivien jälkeen säätyedustajat saivat Venäjälle osoitetun lojaaliuden palkintona kokoontua jälleen vuonna 1863. Periaatteessa uutta lainsäädäntöä ei olisi voinut antaa ilman valtiopäiviä, mutta valtiomuoto tarjosi hyvät mahdollisuudet hallita asetuksin. Oman säädöskokoelman säilyminen antoi hallinnolle ytimen sekä liikkumavaraa, jota ei olisi ollut osana keisarikunnan yleisvaltakunnallista oikeusjärjestystä. Venäläisille ratkaisu oli tehokas, koska uudet alamaiset hallitsivat itse itseään. ${ }^{46}$ Tämä edesauttoi osaltaan sääntelyllisiä poikkeuksia myös Ruotsin vastaisella rajaseudulla verrattuna siihen, jos Suomessa olisi kauttaaltaan sovellettu keisarikunnan yleistä lainsäädäntöä.

Suomen oikeuskulttuurinen side Skandinaviaan säilyi autonomian ajalla vahvana. Yhteisen oikeudellisen historian vuoksi Suomen katsotaan lukeutuvan pohjoismaisen oikeusperheen itäiseen ryhmään yhdessä Ruotsin kanssa. ${ }^{47}$ Oikeusjärjestelmällinen ja -kulttuurinen jatkuvuus oli yksi edellytys sille, että käytännön yhteistoimintaa pystyttiin jatkamaan rajasta huolimatta.

\section{Valtionraja ihmisten välille}

Ihmiset uuden rajan eri puolilla eivät mieltäneet itseänsä eri ryhmiin kuuluviksi. Tornionlaakson eteläosat olivat suomalaisaluetta koko 1800-luvun alkupuolen. Ruotsin viranomaiset kutsuivat Tornionlaakson länsipuolistakin osaa nimellä Finnbygden ja väestöä määreellä finnar. Tornedalingar-nimitys yleistyi vasta 1870luvulta lähtien. Vuosisadan kuluessa Ruotsi-Norjassa poliittinen suhtautuminen suomalaisuuteen jyrkentyi. Skandinaavit pyrittiin asettamaan vastakkain muiden kanssa. Rotuoppien levitessä alettiin esittää näkemyksiä suomalaisen "rodun" alempiarvoisuudesta suhteessa germaaniseen. ${ }^{48}$ Skandinavismin aatesisältö korosti sekin ruotsalaisten ja suomalaisten erottelua. ${ }^{49}$

Ruotsalaiset pelkäsivät, että pohjoisen suomenkieliset asukkaat alkaisivat ajaa Venäjän etua. Tiiviitä yhteyksiä yli rajan pitävien tornionlaaksolaisten ruotsalaistaminen koettiin valtakunnan turvallisuuden vuoksi tarpeelliseksi. Tästä seurasi kielellisiä ja kulttuurisia poikkeuksia karsastaneen nationalismin hengessä voimakasta ruotsalaistamispolitiikkaa. ${ }^{50}$ Norrbottenin lääniin alettiin 1800 -luvun lopulla perustaa oppilaitosverkostoa, millä tähdättiin suomen kielen ja kulttuurin heikentämiseen ja ruotsalaisuuden vahvistamiseen. ${ }^{51}$ Ruotsalaistamisessa katsottiin toimittavan myös tornionlaaksolaisten omaksi parhaaksi. $^{52}$

Lars Elenius on kuvannut Tornionlaakson ruotsalaistamistoimet osana länsimaista valtiovetoista modernisaatiokehitystä, jossa tavoitteena oli vähemmistökulttuurien assimiloinnin lisäksi myös parantaa niiden aineellisia elinolosuhteita ja mahdollisuuksia osallistua yhteiskunnan toimintaan. Samalla päämääränä oli integroida harvaanasutut alueet ruotsalaiseen valtionrakennukseen, mikä vahvistaisi kansallisvaltiota. Suomen kielen käyttämistä saatettiin pitää jopa maanpetoksellisena. ${ }^{53}$ 
Suomessa niin sanottu kansallinen herääminen ilmeni yhtäältä vapautumispyrkimyksinä Ruotsista ja toisaalta yrityksinä säilyttää poliittinen ja henkinen autonomia osana Venäjää. Ero Ruotsista oli synnyttänyt tarpeen rakentaa hallinnollispoliittisen suomalaisuuden ohelle suomalaista kansallistunnetta. Ajan mukaisesti kansallistuntoa etsittiin etenkin kielestä, historiasta ja kansanperinteestä. Myös Suomen Tornionlaaksossa kehitys johti suomen kielen aseman vahvistamispyrkimyksiin ja suomalaisuuden korostamiseen. Ruotsin hallinnon suomalaisuutta alistava politiikka jyrkensi vastakkainasettelua. Myös Suomen puolelle rajan tuntumaan perustettiin oppilaitosverkkoa edistämään kansallisuusaatetta. ${ }^{54}$

Tornionlaakson oikeudellisesta ja poliittisesta rajasta tuli siten keskenään kilpailevien modernisaatio- ja kansallisvaltioprojektien myötä yhä enemmän myös ihmisiä kielellisesti ja kulttuurisesti erotteleva tekijä, mikä on ominaista rajoja korostavalle nationalismille. ${ }^{55}$ Raja-alueet ovat tyypillisesti etnisesti heterogeenisempiä kuin keskusalueet, jolloin valtiolliseen assimilointiin tähtäävät pyrkimykset ovat tärkeitä juuri siellä. ${ }^{56}$ Alun perin varsin vähämerkityksisestä valtionrajasta pyrittiin muodostamaan ihmisiä erotteleva tekijä. Tästä huolimatta rajan ylittävää toimintaa ja yhteistyötä esiintyi koko autonomian ajan. Valtiollinen ja paikallinen kehitys tapahtuivat samanaikaisesti, mutta usein eri suuntiin.

\section{Rajan rakentamista ja ylittämistä}

\section{Asuminen ja taloudelliset oikeudet}

Asuminen ja taloudelliset oikeudet pyrittiin järjestämään siten, että ne noudattaisivat mahdollisimman tarkasti uutta rajalinjaa. Uudenkaupungin (1721) ja Turun (1743) rauhojen yhteydessä vastaavaa ei ollut tehty, mikä oli johtanut riitoihin. ${ }^{57}$ Haminan rauhansopimuksen 10 artiklan mukaisesti sopimuspuolten alamaisilla oli oikeus kolmen vuoden kuluessa asettua kumpaan maahan tahansa. Muutto-oikeuden voimassaoloa pidennettiin myöhemmin. ${ }^{58}$ Samassa artiklassa määrättiin, että rajan toiselle puolelle jäävästä omaisuudesta olisi luovuttava. Etenkään venäläiset eivät halunneet Ruotsin alamaisten pitävän omistuksia Suomessa ja toisaalta tavoittelivat sitä, että Suomessa maata omistavat muuttaisivat Suomeen. Myös tämän määräyksen toteuttamisaikaa pidennettiin. ${ }^{59}$ Eric Anthonin mukaan asumis- ja omistusoikeuksien järjestämisellä pyrittiin heikentämään rajaseudun suomalaisten yhteenkuuluvuuden tunnetta entiseen emämaahansa. $^{60}$

Rauhansopimuksen 5 artiklan nojalla rajalinja oli määritettävä rajankäynnissä tarkemmin, joten rajanjärjestelysopimus ratifioitiin joulukuussa $1810 .{ }^{61}$ Omistusolojen järjestämiseksi ryhdyttiin toimeenpanemaan tilusvaihtoja, aluksi vapaaehtoispohjalta ja mahdollisimman paljon sukulaisten kesken. ${ }^{62} \mathrm{Va}$ paaehtoisvaihtoja ei kuitenkaan tehty riittävästi, joten niiden laajentamiseksi ja lopulliseksi järjestämiseksi laadittiin konventio, joka sisälsi tilusvaihdoissa ja muussa maaomaisuuden järjestelyissä noudatettavat periaatteet. Vaihdot sekä niihin liittyvät riidat korvauskysymyksineen saatiin käsiteltyä sekä julistus tilusvaihtojen loppuun saattamisesta ja vahvistamisesta allekirjoitettua syyskuussa $1823 .{ }^{63}$ 


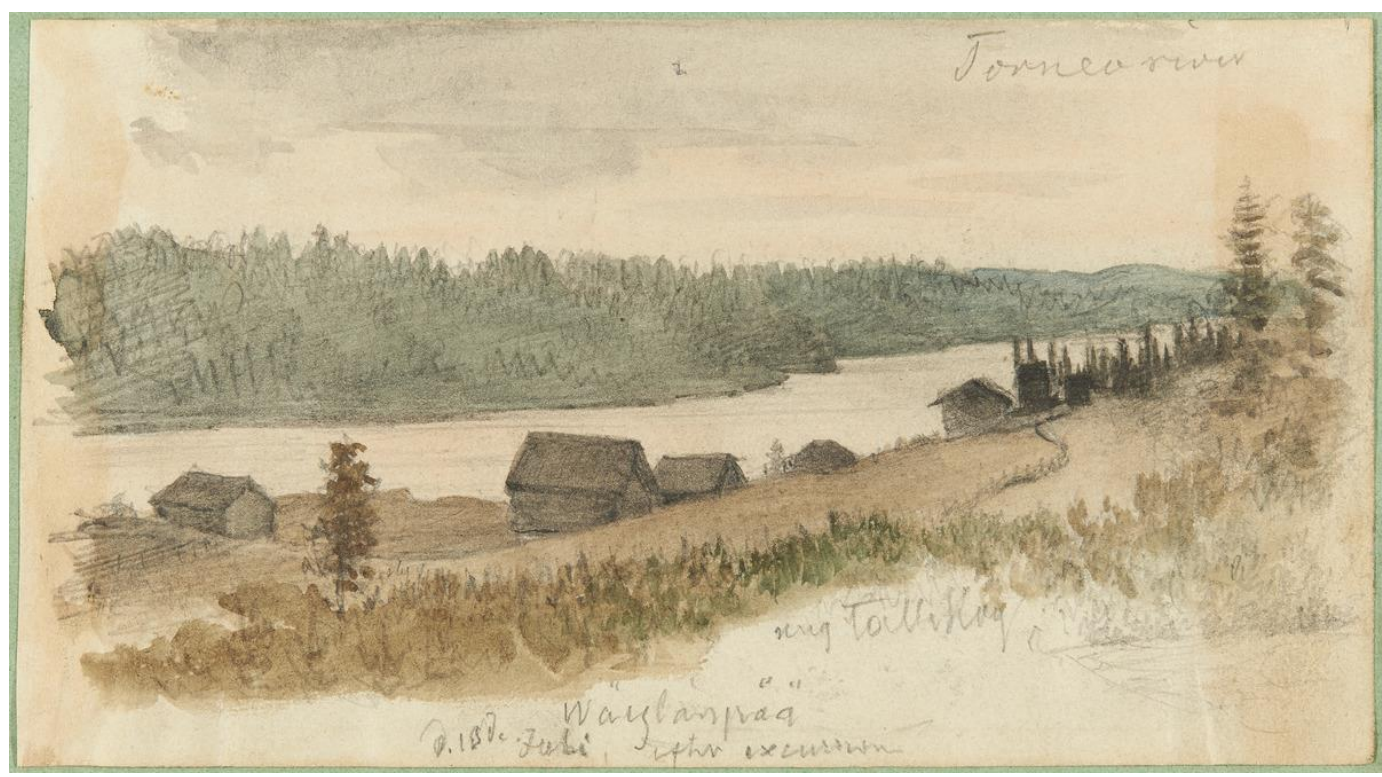

Kuva 2. Näköala Tornionjoelta. Vesivärimaalaus 1800-luvun puovälistä, A.F./C.E. Soldan. Museovirasto

Tornion- ja Muonionjoissa sijaitsee niittysaaria, jotka olivat maanviljelyksen kannalta tärkeitä. Vaikka venäläiset eivät suostuneet entisten nautintojen säilyttämiseen mantereella, poikkeusjärjestely rajajoissa olevilla saarilla sopi, mikäli tilusvaihdot eivät omistus- ja nautintaolosuhteiden monimutkaisuudesta johtuen onnistuneet. ${ }^{64}$ Niinpä vuoden 1810 rajanjärjestelysopimuksen 2 artiklan mukaisesti saarten aikaisemmille omistajille taattiin ikuinen nautintaoikeus saariin, vaikka rajalinja kulkisi saaren vastakkaiselta puolelta. Saarten käyttöä rajoitettiin kuitenkin esimerkiksi siten, että rakentaminen oli pääsääntöisesti kielletty, eikä saarten haltijoilla ollut oikeutta kalavesiin. ${ }^{65}$ Oikeudesta oli suoritettava lähinnä symbolinen ns. suvereniteettimaksu (à l'autre Souverain) sille, jolle saari kuuluu.

Tilusvaihdon päättyessä Ruotsin alamaisilla oli Suomessa 15 saarta, joista neljä vain osaksi, ja Suomen alamaisilla Ruotsissa 36 saarta joista yksi vain osaksi. ${ }^{66}$ Syväväylän siirtymisen saarten kohdalla ei katsottu aiheuttavan muutosta valtakunnanrajaan. Rajamuutokset olisivat rauhansopimuksen ja rajanjärjestelysopimuksen tarkoituksen vastaisesti aiheuttaneet yksityisen omaisuuden siirtoja valtakunnasta toiseen. ${ }^{67}$ Tulkinta saarten kiinteistöoikeudellisesta asemasta ei ollut yksiselitteinen: Suomen isojaossa saaria ei otettu huomioon, koska niihin katsottiin olevan vain käyttöoikeus. Ruotsissa saaret sen sijaan otettiin mukaan jakoihin ja osittamisiin muiden tilusten tavoin. ${ }^{68}$

Uusi raja herätti myös kysymyksiä oikeuksista kalastukseen, joka saattoi paikoin olla jopa pääelinkeino. ${ }^{69}$. Tornionjoen karsinapatojen lohenkalastus oli vuonna 1791 vuokrattu sadaksi vuodeksi jokivarren pitäjien ja saarten asukkaille. Uusi raja halkaisi perinteisen kalastusalueen ja jakoi sen asukkaat eri valtakuntiin. Ruotsi ja Venäjä pääsivät sopuun lohenkalastuksen jatkamisesta alamaistensa kesken yhteisesti sekä verotuoton jakoperusteesta. Muun kalastuksen osalta valtakunnanraja tuli kalastusoikeuksien rajaksi. ${ }^{70}$ Vuonna 1901 lohenkalastusoikeuksien myöntämisessä siirryttiin valtioille tuottoisiin vuosittaisiin huutokauppoihin, jotka pidettiin vuorovuosin Torniossa ja Haaparannalla. ${ }^{71}$

Asumisen ja taloudellisten oikeuksien järjestäminen valtakunnan rajaa noudattavaksi osoittaa, että raja tuli merkitsemään konkreettista oikeudellista erottelua. Periaatteelliset linjat sovittiin poliittisella ylätasolla, mutta vaikutukset kohdistuivat paikallisiin. Kuitenkin suvereniteettisaarijärjestely ja yhteisen lohenkalastuksen jatkaminen kertovat, että valtiot kykenivät sopimaan myös paikalliset olosuhteet huomioivista erityisjärjestelyistä. 


\section{Liikkuminen}

Suomen sodan venäläismiehityksen aikaan liikkumista Ruotsin puolelle ei nähtävästi estetty ja moni sïrtyi sinne seuraamaan tilanteen kehittymistä. ${ }^{72}$ Haminan rauhansopimuksen artiklat eivät nekään sisältäneet erityisiä menettelymääräyksiä rajan ylittämisestä. Kuten todettu, sopimuksen 10 artikla takasi vapaan muutto-oikeuden määräajan kuluessa. ${ }^{73}$ Vuoden 1810 rajanjärjestelysopimuksen 4 artiklassa määrättiin, että rajan kummallakin puolella olevien asukkaiden siihen saakka käyttämät välttämättömät sekä kaupankäynnin kannalta tarpeelliset vesi- ja maaliikenteen kulkuyhteydet taataan myös tulevaisuudessa. ${ }^{74}$ Esimerkiksi tieyhteys Ylitorniolle (Övertorneå) meni vain joen länsipuolta. Itäpuolen tie valmistui $1829 .{ }^{75}$ Tulkintaepäselvyyksien oikaisemiseksi vuonna 1845 annettiin rajanjärjestelysopimuksen määräyksiä täsmentävä julistus. ${ }^{76}$

Kanssakäyminen rajan yli jatkui siis aluksi pääosin entiseen tapaan. Kun rajaliikennettä myöhemmin alettiin kontrolloida, se tehtiin eritoten taloudellisiin etuihin liittyvistä syistä. ${ }^{77}$ Vaikka rajaseudun asukkaiden liikkuminen rajan yli oli vapaata, yleisesti Suomessa sovellettiin ruotsinaikaisia ulkomaanmatkoja koskevia asetuksia, eikä Ruotsiin matkustaminen ilman erityisperusteita ollut sallittua. ${ }^{78}$ Paikallisista lievennyksistään huolimatta liikkumista koskeva sääntely erotteli pohjoisen rajaseudun ihmiset oikeudellisesti eri ryhmiin. John Torpeyn mukaan rajaliikenteen kontrolloinnin kehittyminen havainnollistaa kansallisvaltioajatuksen institutionalisoitumista ja konkretisoitumista: valtio päättää, mikä on hyväksyttävä ja laillinen syy liikkumiseen. ${ }^{79}$

Vuonna 1811 annettua autonomian ajan ensimmäistä ulkomaalaisasetusta sovellettiin vain Suomessa. Asetus koski Ruotsista Suomeen matkustavia ja sisälsi perusteita viisumivapaalle matkustamiselle huomioiden myös rajaseudun olosuhteet. ${ }^{80}$ Vuonna 1829 alettiin soveltaa Suomen ja Ruotsin välillä sovittua vastavuoroista menettelyä, jossa ruotsalaiset saivat matkustaa Oulun ja Vaasan lääneissä ja suomalaiset Norrbottenin ja Västerbottenin lääneissä pelkällä passilla. ${ }^{81}$ Passi oli esitettävä tullissa ja poliisiasemalla, jos viipyi yli kaksi päivää. ${ }^{82}$ Rajan ylittävät vierailut olivat todennäköisesti usein tätä lyhyempiä.

Ruotsissa säädettiin vuonna 1860 passivapaus, jota tiukennettiin vasta ensimmäisen maailmansodan aikaan. Kuka tahansa ulkomaalainen sai tulla Ruotsiin passitta. ${ }^{83}$ Tämä vastasi ajan eurooppalaista kehitystä, jossa liberalismin hengessä vapautettiin paitsi taloudellista toimintaa myös maahan tulemisen ja maasta poistumisen käytäntöjä. ${ }^{84}$ Todennäköisesti muutos ei ollut pohjoisen rajaseudun asukkaille kovin suuri ottaen huomioon jo vallinneet helpotukset.

Venäjä ja Suomi sen osana sen sijaan säilyivät 1800-luvulla muuta Eurooppaa suljetumpana. ${ }^{85}$ Sääntelyllistä epätahtisuutta kuvaa, että Suomessa ensimmäinen varsinainen passiasetus annettiin vasta 1862, Ruotsin passivapauden jälkeen. Säädöksen 9 \:ssä ja 15 \:ssa kuitenkin taattiin aiempien käytäntöjen jatkuminen Suomen ja Ruotsin pohjoisten läänien välillä sekä erikseen todettiin, että asetuksen muu sääntely ei tarkoittanut muutosta raja-alueen asukkaille sen osalta, mitä vuoden 1810 rajanjärjestelysopimuksessa ja vuoden 1845 julistuksessa määrättiin. ${ }^{86}$ Vuoden 1888 passiasetus, autonomian ajan viimeinen, ei enää sisältänyt viittauksia aiempaan sääntelyyn. Kuitenkin sen 2 \:n ja 9 §:n säännökset uudistivat jo aiemmin voimassa olleet lievennykset suomalaisten liikkumisesta Pohjois-Ruotsiin ja ruotsalaisten saapumisesta Pohjois-Suomeen. ${ }^{87}$

Rajan ylittävää liikkumista koskevan sääntelyn yhteydessä on huomioitava, että niin Suomessa kuin Ruotsissa liikkuminen maan sisällä oli pitkään tiukasti rajoitettua ja luvanvaraista. ${ }^{8}$ Tätä taustaa vasten pohjoista rajaseutua koskenut rajan ylittävän liikkumisen sääntely oli sallivaa. 


\section{Liikenne- ja viestintäyhteydet}

Sääntelyllisistä helpotuksista riippumatta yhteyksiin liittyi käytännön ongelmia. Vaikka rajajoet olivat entiseen tapaan tehokkaita kulku- ja kuljetusväyliä, siltoja niiden yli ei vielä ollut. Merkittävä parannus Torniossa oli yksityishenkilön vuonna 1886 rakennuttama puinen kävelysilta joen yli. Se sai virallisen hyväksynnän Tornion ja Haaparannan päätöksentekoelimissä, ja kaupungit ostivat vilkkaasti liikennöidyn sillan 1920-luvulla itselleen. Kulkuyhteyksien paikallinen parantaminen on osoitus siitä, että rajan ylittävää toimintaa edistettiin kieli- ja kansallisuuspoliittisten suhdanteiden kiristymisestä huolimatta.

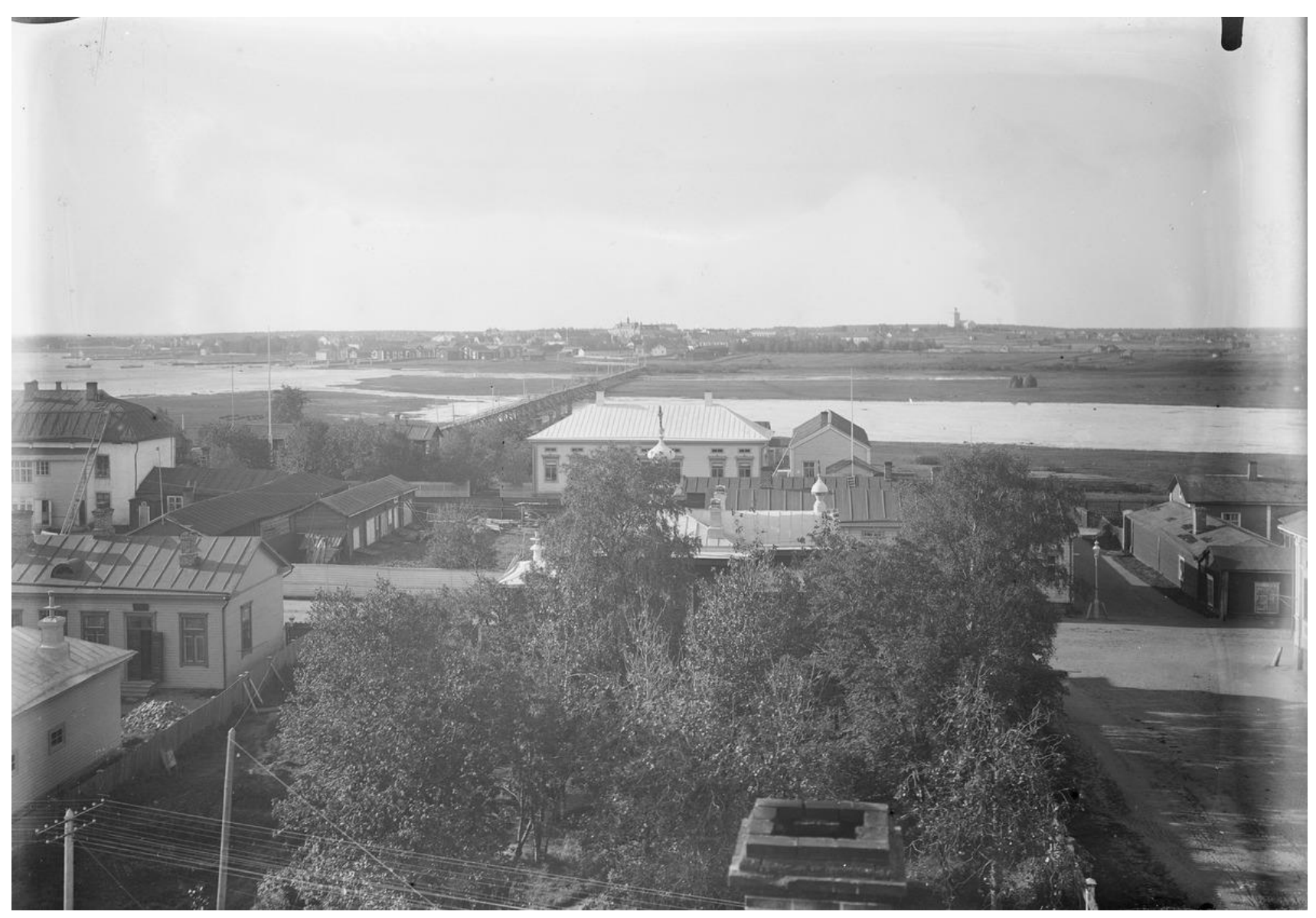

Kuva 3. Tornion ja Haaparannan yhdistävä kävelysilta. Museovirasto

Valtiollisella tasolla rautatien rakentaminen pohjoiselle rajalle vahvisti alueen taloudellista ja strategista merkitystä. Venäjän rautatiepolitiikan yhtenä tarkoituksena oli kytkeä Suomi kiinteämmin keisarikuntaan. Rajaseutujen raideyhteyksien sotilaallisen merkityksen kasvu oli yleiseurooppalainen ilmiö. ${ }^{89}$ Vuoden 1897 säätyvaltiopäivät päätti radan rakentamisesta Tornioon ja se valmistui vuonna 1903. Yhteys Ruotsiin tapahtui höyrylautalla. Sotilasstrategisten uhkien lisäksi venäläisiä aiheellisesti pelotti, että kiskoja pitkin etenisi keisarikunnan poliittisen vakauden kannalta vaarallisia aatteita ja henkilöitä. ${ }^{90}$

Ruotsissa ja Norjassa taas Venäjä koettiin uhaksi ja venäläisen rataverkon laajentaminen epäilyttäväksi. ${ }^{91}$ Rata rajalle voisi heikentää Suomen merkitystä Venäjän vastaisena puskurialueena. ${ }^{92}$ Ruotsissa ajateltiin, että Venäjä pyrkii kohti Atlanttia. Silti Ruotsi halusi yhdistää pohjoiset alueet raitein valtakuntaansa. Pohjoisen suomalaisväestö nähtiin uhkaksi, jos se kääntyisi Venäjän suuntaan. Toisaalta radan ajateltiin auttavan suomalaisalueen ruotsalaistamisessa. ${ }^{93}$ Rata rajalle Ruotsin puolen Karunkiin valmistui vasta $1913 .^{94}$ 
Epäluuloista huolimatta pohjoisrajan yli kulki myös viestintäyhteyksiä. Lennätinyhteys rakennettiin aluksi Kukkolankoskelle, mutta siirrettiin myöhemmin Tornioon. Haaparannan lennätinasema valmistui vuonna 1856. Yleisvaltakunnallisen hallinnon alainen Venäjän lennätinkonttori toimi siten Ruotsin valtakunnan puolella vuoteen 1908 asti. ${ }^{95}$ Tämä on mielenkiintoista, koska venäläiset pitivät lennätintä sotilaallisesti tärkeänä ja myös sen mahdollistaman nopean viestinnän taloudellinen merkitys kasvoi. ${ }^{96}$

Puhelintoiminnan sääntely tai sen toimeenpano ei ollut 1800-luvulla vielä selkiytynyt. Venäjältä puuttui yhtenäinen puhelinlainsäädäntö: luvat ratkaistiin tapauskohtaisesti. Tornion ja Haaparannan välinen puhelinyhteys toimi 1880-luvulla ilmeisesti täysin epävirallisesti paikallisten liikemiesten yksityisiä linjoja pitkin. ${ }^{97}$ Tornion puhelinlaitos valmistui vuonna 1898 . Tuolloisten toimilupaehtojen nojalla puhelinjoja saatiin vetää viiden kilometrin säteellä. Paikallisesti tätä tulkittiin niin, että johtoja vedettiin myös Haaparannalle. Puhelinjoja koskevat lupahakemukset menivät Venäjän ulkoasianhallinnon käsiteltäviksi, koska Suomen senaatin toimivaltuudet eivät ulottuneet rajat ylittäviin linjoihin. Keisarillinen lupa rajan ylittävään puhelinyhteyteen myönnettiin vuonna 1900 sillä ehdolla, että viranomaiset saisivat tarpeen vaatiessa katkaista linjan välittömästi: suora puhelinyhteys Tukholmaan haluttiin tarvittaessa estää. ${ }^{98}$

Rajan ylittävien viestintäyhteyksien sallittavuus riippui poliittisista oloista: venäläistämistoimien kiristyessä puhelinlinjat Ruotsiin katkaistiin, otteen hellittäessä lupia myönnettiin, tilanteen jälleen kiristyessä uudet lupa-anomukset evättiin. Keisarikunnan vuoden 1908 uuden esittelyjärjestyksen myötä pohjoisen länsirajan ylittävät puhelinyhteydet katsottiin koko keisarikunnan etuja koskeviksi. Venäläisten mukaan uusia lupia ei voitaisi myöntää niiden kansainvälisen luonteen vuoksi ennen kuin suomalainen puhelintoiminta olisi venäläisten valvonnassa ja poliittinen tilanne tyynempi. Linjoja pitkin pelättiin kulkevan vallankumoushenkeä. ${ }^{99}$

Liikenne- ja viestintäyhteydet havainnollistavat, miten suurvaltapoliittiset sekä Venäjän sisäpoliittiset suhdanteet vaikuttivat suoraan pohjoiseen rajaseutuun. Toisaalta paikallisesti saatettiin tehdä omavaltaisia ratkaisuja, kuten rakentaa rajan yli linjoja lupia kyselemättä. Oscar J. Martinezin mukaan rajaseutujen luonteeseen usein kuuluu, että keskusvallan sääntelyä venytetään tai sivuutetaan. Näin toimitaan, jos sääntelyn koetaan häiritsevän rajan ylittävän vuorovaikutuksen totuttua järjestystä. ${ }^{100}$ Omalakisuus kertoo myös siitä, että venäläisperäisen sääntelyn rikkomista ei usein nähty ristiriitaiseksi lainkuulaisuuden kanssa. Tämä asenne tuli jatkumaan pohjoisella länsirajalla myös Suomen itsenäistyttyä. ${ }^{101}$

\section{Rajavalvonnan ja taloudellisen toiminnan kytkös}

Oman tullialueen ja tullilaitoksen perustaminen oli osoitus siitä, että Suomi oli oma oikeudellishallinnollinen yksikkönsä. Vastoin Venäjän alkuperäistä ajatusta tulliraja tuli koskemaan myös Suomen ja Venäjän välistä rajaa. Tärkeänä perusteena oli Ruotsin kaupallisen erityiskohtelun mahdollistaminen. Suomessakin toivottiin, että Ruotsin-kauppa olisi mahdollisimman vapaata. Päätösvalta tulleista kuului hallitusmuodon nojalla keisarille, tullilaitoksen valvonta vuoden 1812 tullihallinto-ohjesäännön mukaisesti hallituskonseljille (senaatille). ${ }^{102}$ Tullilaitoksen järjestämisen ajan noudatettiin Ruotsin aikaisia tullitaksoja. ${ }^{103}$ Tullirajan toteuttaminen edellytti rajakontrollia.

Rauhanteon jälkeen venäläistä sotaväkeä jäi rajalle vartiopalvelukseen ja muiden keisarikunnan rajojen tapaan myös luoteisrajalla oli kasakoita. ${ }^{104}$ Tornioon perustetun suomalaisen tullikamarin tehtävänä oli pohjoisimman merirajan lisäksi valvoa myös läntistä maarajaa. ${ }^{105}$ Rajalle 1840 -luvulla asetettujen rajaviskaalien ja tullivartijoiden tuli erityisesti estää salakuljetusta. Vuosisadan loppua kohti rajaviranomaisten määrää edelleen lisättiin vilkastuneen salakuljetuksen torjumiseksi. ${ }^{106}$ Aliresursoitu maarajan 
valvonta oli kuitenkin varsin löyhää, eikä rajaseudulla katsottu tullisäädösten noudattamista tärkeäksi. ${ }^{107}$ Keisarikunnan viranomaiset pitivät suomalaisten tullivalvontaa tehottomana. ${ }^{108}$

Ruotsalaisten kannalta kaukaisen rajaseudun merkitys kasvoi uusien liikenne- ja viestintäyhteyksien myötä. Tämä näkyi alueen puolustuksen ja valvonnan vahvistumisena. ${ }^{109}$ Haaparantaan asetettiin vuonna 1811 rajakomppania, joka osittain koostui lakkautettujen suomalaisrykmenttien sotilaista. ${ }^{110}$ Myöhemmin Norrbotteniin perustettiin vakinaiskaarti, johon värväytyi vapaaehtoisesti paljon suomenkielisiä. Sotilasopintojen lisäksi koulutukseen sisältyi ruotsinkielistä yleissivistävää opetusta, joten joukkojen koulutus oli myös osaksi rajaväestön ruotsalaistamistoimintaa. ${ }^{111}$ Tullitointa hoitaneen Haaparannan tullikamaripiirintoiminta-alue ulottui pohjoisessa aina Karesuvantoon asti. ${ }^{12}$

Rajakontrollia ei vahvistettu niinkään paikallisten kontrolloimiseksi kuin taloudellisten etujen valvomiseksi. Kauppasuhteiden jatkuminen oli olennaista. Suomelle oli tärkeää saada viedä maataloustuotteitaan Ruotsiin, joka niitä edelleen tarvitsi. Ulkomaantavaroiden kuljetus onnistui ympärivuotisesti maitse vain Tornion kautta. ${ }^{113}$ Haminan rauhansopimuksen 16 ja 17 artiklojen mukaisesti kaupankäynti palautettiin ja säilytettiin lokakuuhun 1811 saakka sellaisena kuin se oli ennen sotaa. Määräykset sisälsivät myös luettelon vienti- ja tuontivapaista tuotteista. ${ }^{114}$ Sopimuksen 17 artiklan voimassaoloa jatkettiin Venäjän ja Ruotsin vuoden 1812 hyökkäys- ja puolustussopimuksen yhteydessä vuoden 1815 loppuun. ${ }^{115}$ Vastaavasti pidennettiin pohjoista raja-aluetta koskeneiden 10 ja 15 artiklojen voimassaoloa. ${ }^{116}$

Vuoden 1810 rajanjärjestelysopimus sisälsi yleisen tason sääntöjä rajakaupan vapaudesta omaa käyttöä ja välitöntä tarvetta varten, mitä paikalliset sovelsivat laventavasti. ${ }^{117}$ Rajanjärjestelysopimuksen tulkintaa ohjanneella vuoden 1845 julistuksella pyrittiin kitkemään omavaltaisia tulkintoja: toiseen valtioon ei saanut kuljettaa tullisääntelyn piirissä olleita hyödykkeitä, pois lukien jyvien ja muiden välttämättömyystarvikkeiden kauttakuljetus. Erikseen mainittiin, että paloviina ja muu alkoholi ei kuulunut vapautettuihin välttämättömyystarvikkeisiin. ${ }^{118}$

Ruotsin ja Venäjän ensimmäinen Suomen aseman muuttumisen jälkeinen kauppasopimus tuli voimaan vuonna 1818 ja merkitsi tullien kiristämistä sekä muun muassa maataloustuotteiden tullittoman Ruotsiin viennin loppumista eräistä lievennyksistä huolimatta. ${ }^{119}$ Seuraavien kauppasopimusten myötä maataloustuotteiden tullimaksuja korotettiin edelleen, mikä vaikeutti entisestään vientiä Ruotsiin. ${ }^{120}$ Silti Tornion kautta kulkenut kauppa suuntautui vielä pitkään Tukholmaan. ${ }^{121}$ Uusi raja haittasi myös Lapin kauppaa, koska se halkaisi pohjoisen kauppa-alueen. ${ }^{122}$ Vaikka kaupalliset syyt olivat tärkein vaikutin Tornion liittämiseen osaksi Venäjää, raja heikensi alueen taloudellisia mahdollisuuksia. ${ }^{123}$

Osa aiemmin Tornion puolella asuneista kauppiaista käytti rauhansopimuksessa taattua oikeutta ja muutti Ruotsin puolelle, vaikka muuttoliike jäi pelättyä vähemmäksi. Ruotsiin asettuneet kävivät kauppaa ruotsalaisilla sisämarkkinoilla ja välttyivät ulkomaankaupan tullimaksuilta. ${ }^{124}$ Myös kiinteistöjen ja tuotantolaitosten rajan ylittävän omistamisen rajoitukset saattoivat olla syy muuttoon. Omistussääntelyn kiertämiseksi osattiin käyttää bulvaaneja, mikä mahdollisti tosiasiallisen ulkomaalaisomistamisen. ${ }^{125}$ Tiiviit henkilökohtaiset yhteydet helpottivat sääntelyn kiertämistä.

Tornion menettäminen aiheutti hankaluuksia Ruotsille, joka myönsi vuonna 1842 Haaparannalle kaupunkioikeudet. Tornion kilpailukyky koettiin heikoksi ja sen asemaa pyrittiin parantamaan muun muassa tapulivapaudella. ${ }^{126}$ Etenkin tullisääntelyn nopeat ja vaikeasti ennakoitavat muutokset vaikuttivat kiivaasti kilpailtuun rajakauppaan. Kaupankäynnin suunta ja volyymi vaihteli äkillisesti sen mukaan, mikä oli edullisinta. ${ }^{127}$

Elinkeinovapaus ja siihen liittyvä laaja tullivapaus toteutettiin länsinaapurissa Suomea aiemmin. ${ }^{128}$ Tämän myötä Suomen puolen maalaisväestö alkoi käydä kauppaa suoraan rajan länsipuolella. Torniolaiskauppiaat vaativat maakaupan laittamista kuriin, tullien laskemista sekä rajavalvonnan tehostamista, jotta ulkomaankauppa saataisiin taas kulkemaan siihen yksinoikeutettujen kauppiaiden kautta. ${ }^{129}$ Tiukat vienti- 
ja tuontimääräykset sekä niiden valvonta eivät siten olleet kaikille ongelma: kanta riippui omasta edusta. Ruotsin ja Suomen kauppapolitiikan sääntelyllinen epätahtisuus leimasi joka tapauksessa rajaseudun taloudellisia oloja.

Kilpailun ohella tehtiin silti rajan ylittävää yhteistyötä ja pankit lainoittivat liikemiehiä rajasta huolimatta. ${ }^{130}$ Elinkeinotoimintaa edesauttoivat tiiviit epäviralliset yhteydet, joita hyödyntäen oli helpompaa toimia eritasoisesta sääntelystä riippumatta. ${ }^{131}$ Elinkeinotoiminnan koordinoinnin hengessä toteutettiin esimerkiksi rajan ylittävä oluen hintakartelli. ${ }^{132}$ Alkoholi oli jo tuolloin tärkeä raja-aluekysymys ja Ruotsin sääntely vapaampaa. Siksi Suomen puolellakaan alkoholin myyntiä ja anniskelua ei voitu liiaksi rajoittaa. Muuttuviin tilanteisiin reagoimista helpotti, että päätäntävalta alkoholikysymyksissä oli kunnallistasolla, Torniossa kaupunginvaltuustolla. ${ }^{133}$

\section{Monenkirjavaa toimintaa yli rajan}

Vaikka uusi raja merkitsi ihmisten jakoa kahteen eri valtakuntaan, arkipäiväinen toiminta jatkui myös rajan yli: rajaseudun asukkaat kokivat rajan todellisuudestaan irralliseksi. ${ }^{134}$ Martinezin mukaan tämä on tyypillistä raja-alueilla, joilla ihmiset usein elävät useammassa kuin yhdessä sosiaalisessa todellisuudessa: esimerkiksi yhtäältä kansallisessa ja toisaalta raja-alueen todellisuudessa. ${ }^{135}$ Valtiollisen rajaa rakentavan ja paikallisen rajasta välittämättömän toiminnan erisuuntaisuus ilmeni myös Tornionlaaksossa.

Kanssakäymisen tiiviyttä kuvaa rajan ylittävien avioliittojen runsaus. Vielä 1800-luvun loppuvuosikymmeninä Torniossa vihityistä pareista 15 prosentissa tapauksista sulhanen oli kotoisin Ruotsista: tapana oli vihkiä morsiamen kotipaikkakunnalla. ${ }^{136}$ Vastaavasti suomalaismiesten avioituminen Ruotsissa oli yleistä. Ruotsin teollistuminen kasvatti elintasoeroa ja veti paremman toimeentulon perässä muuttajia. ${ }^{137}$ Käytännössä muutto ei merkinnyt kulttuurishokkia, koska myös ruotsinpuoleinen Tornionlaakso oli kielellisesti ja kulttuurisesti pitkään lähes täysin suomalainen.

Seurakunnat toimivat aluksi rajan yli. Suomalaiset merkittiin Ruotsissa sijainneen kotikirkkonsa kirkonkirjaan määreellä "Venäjän alamainen". ${ }^{138}$ Kuitenkin Haminan rauhansopimuksen nojalla myös seurakuntien omaisuus oli jaettava rajalinjaa myöten. ${ }^{139}$ Suomen senaatti julisti kirkollisen valtionrajan ylittävän yhteyden päättyneeksi syyskuussa 1820, jolloin uudet kirkot ja pappilat oli molemmin puolin rakennettu. ${ }^{140}$

Monien oli virallisesta kirkollisen yhteyden lakkaamisesta huolimatta mentävä rajan toiselle puolelle saadakseen kuulla sanaa äidinkielellään. Tornionlaaksossa pidettiin rajan molemmin puolin usein ainoastaan suomenkielisiä jumalanpalveluksia. Toisaalta etenkin Tornion säätyläistö oli Ruotsin vallan loppuvuosina ruotsalaistunut siinä määrin, että 1800-luvun alkupuolella kaupungissa ei pidetty lainkaan suomenkielisiä päiväjumalanpalveluksia. Tukholmassa paheksuttiinkin ruotsalaisten kirkossakäyntiä rajan itäpuolella. Kirkollisten toimitusten kieli liittyi myös oikeudellisiin oloihin, koska sääntely tuli väestön tietoon pääasiassa kirkossa luettuina kuulutuksina. Nämä jäivät esimerkiksi Torniossa ruotsia taitamattomilta ymmärtämättä, eikä toisaalta Ruotsin suomenkielinen väestö usein ymmärtänyt ruotsalaista lainsäädäntöä. ${ }^{141}$ 


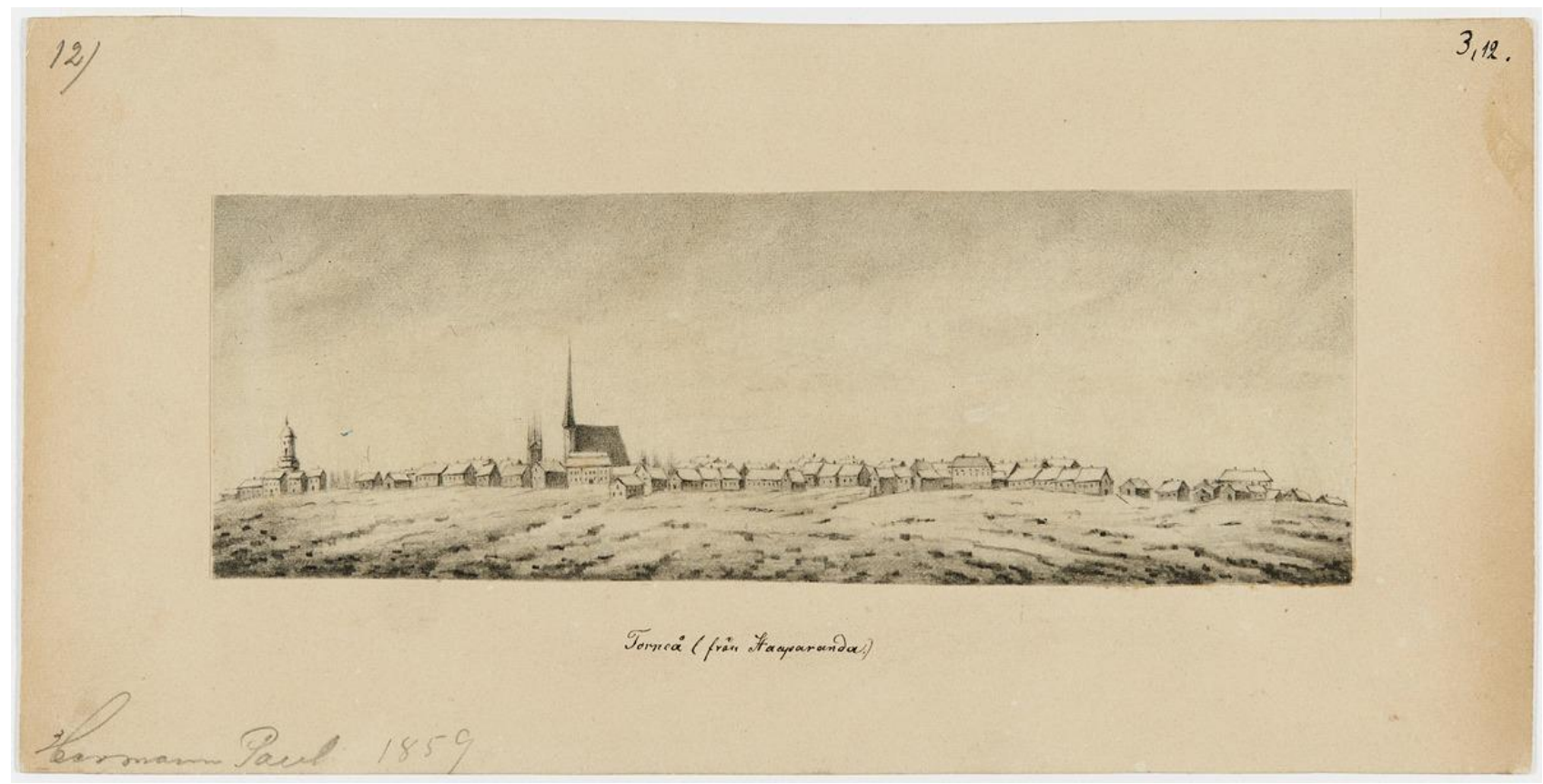

Kuva 4. Tornio Haaparannalta näbtynä. Hermann Paulin piirros vuodelta 1859. Museovirasto

Raja-alueen pohjoisosista etelään 1800-luvun puolivälissä nopeasti levinnyt lestadiolaisuus oli yksi tärkeä rajan yli tapahtuvan vuorovaikutuksen kanava. ${ }^{142}$ Lestadiolaisuus myös ylläpiti suomen kielen asemaa Tornionlaaksossa ja toimi silläkin tavoin väestöä yhdistävänä tekijänä. Liike kuitenkin myös erotteli ihmisiä lestadiolaisten ja ei-lestadiolaisten välillä, mutta tämä jako ei noudattanut valtionrajaa. ${ }^{143}$

Koulunkäynti ulottui niin ikään rajan yli. Etenkin torniolaisia kävi Ruotsissa koulua ja monet myös jatkoivat vanhoja perinteitä kulkien opintietä ruotsalaisyliopistoihin. Haaparannalle 1850-luvulla perustettuun yläalkeiskouluun tuli myös Torniosta oppilaita, joiden olisi muutoin täytynyt suunnata jatko-oppiin kauemmas. ${ }^{144}$ Alkeisopetus hoidettiin, jos hoidettiin, vuoden 1686 kirkkolain nojalla kotikutoisesti vanhempien äidinkielellä, eli ruotsinpuoleisessakin Tornionlaaksossa suomeksi. Vuoden 1842 kansakouluasetuksen myötä Ruotsiin alettiin perustaa kansakouluverkkoa, joka laajentui Tornionlaaksoon vasta 1850-luvulta alkaen. Opetus järjestettiin väestön omalla kielellä eli suomeksi ja alkuun suomalaisin koulukirjoin. Vaikeutena oli löytää suomenkielisiä opettajia. ${ }^{145}$

Etenkin 1870-luvulta lähtien Ruotsissa aloitettiin toimet, jotka johtivat koululaitoksen ruotsinkielistämiseen. Aluksi ruotsi oli vapaaehtoinen oppiaine, mutta muuttui pian opetuskieleksi, vaikka usein suomenkieliset koululaiset eivät sitä ymmärtäneet. Muutokseen liittyi monia aiemmin käsiteltyjä yhteiskunnallisia tekijöitä. Tarkoitus oli kasvattaa rajaseudun väestöstä aitoja Ruotsin kansalaisia. ${ }^{146}$ Vaikka paikalliset asukkaat eivät kaiketi kannattaneet kaiken opetuksen ruotsinkielistämistä, kielen oppimista saatettiin kuitenkin pitää hyödyllisenä esimerkiksi työelämän kannalta. ${ }^{147}$ Rajan länsipuolen väestö oli myös aina kuulunut Ruotsiin ja tunsi yhteenkuuluvaisuutta Ruotsin valtioon. Se halusi mieluummin olla kaksikielistä kuin joko suomen- tai ruotsinkielistä. ${ }^{148}$

Myös Suomessa oli 1860-luvulle saakka voimassa Ruotsin vuoden 1686 kirkkolaki, joka velvoitti vanhemmat opettamaan lapsilleen lukutaidon alkeet. ${ }^{149}$ Vuoden 1866 kansakouluasetuksesta huolimatta koulujen perustaminen pohjoiseen sujui verkkaisesti. Kouluverkko levisi pohjoisimmallekin rajaseudulle vuosisadan loppuun mennessä ja myös kirkollisen kiertokoulun järjestäminen vähensi vanhempien opetusvastuuta. ${ }^{150}$ Koululaitoksen nopeampi leviäminen Ruotsin pohjoisosiin merkitsi sitä, että ainakin jotkut Suomen puolella asuvat saattoivat saada opetuksensa rajan länsipuolella. ${ }^{151}$ Kokonaistasolla koulutoimi oli kuitenkin yksi keino, joka edesauttoi rajaseudun ihmisten erottelua. 
Tiedonvälitys oli myös rajan ylittävä ala. Vielä vuosisadan loppupuolella Haaparannalla ilmestyi useita suomenkielisiä lehtiä, joissa oli laajojakin Suomea käsitelleitä osioita. Lyhyen ajan jopa Tornion kaupungin viralliset ilmoitukset julkaistiin Haaparannanlehden erillisosiossa. Tämä herätti luonnollisesti huolta venäläisviranomaisissa, jotka eivät voineet kontrolloida Ruotsin puolen kirjoittelua. ${ }^{152}$ Ruotsissa Suomen asioista voitiin uutisoida vähemmin pidäkkein.

Sensuurin kiristyessä ulkomaisten lehtien tuontikontrollia tehostettiin Suomessa. Huomio kiinnittyi ruotsalaisiin sekä norjalaisiin lehtiin. Sensuuritoiminta synnytti maanalaisen suomalaisen lehdistön. Painotyö hoidettiin Ruotsissa ja lehdet salakuljetettiin Suomeen. Länsirajan suomalaisvirkakunta ei kuitenkaan antanut sensuuriviranomaisille tehokasta virka-apua lehtien salakuljetuksen estämiseksi, pikemminkin päinvastoin. ${ }^{153}$

Ihmisten välinen yhteistoiminta ylitti rajan lisäksi muun muassa raittiusseuratoiminnan, kulttuurin ja urheilun aloilla. ${ }^{154}$ Yksi harvoista virallisen yhteistyön kohteista olivat Tornion ja Haaparannan yhteiset ruoppaushankkeet 1800-luvun jälkipuolella. Ne palvelivat molempien kaupunkien merenkulkua ja kustannukset pääsääntöisesti puolitettiin. ${ }^{155}$ Kaiken kaikkiaan toiminta yli rajan oli luonteeltaan mutkatonta, paikallista ja varsin epämuodollista. Kuitenkin 1900-luvun alkuvuosina sisä- ja suurvaltapoliittinen tilanne kiristyi, mikä heijastui rajaseudulle.

\section{Suurvaltapolitiikan sivuvirrassa}

\section{Rajaolojen kiristyminen}

Reuna-alueiden venäläistämiseen ja tiiviimpään keisarikuntaan integrointiin tähdännyt toiminta voimistui vuosisadan vaihteessa. Jo 1800-luvun lopulla tavoitteena oli ollut yhdenmukaistaa keisarikunnan lainsäädäntömenettelyjä siten, että valtakunnan lakeja voitaisiin saattaa suoraan voimaan ja sovellettavaksi ilman suomalaisia voimaansaattamistoimia. Helmikuun 1899 manifestilla poistettiin suomalaisilta valtioelimiltä päätösvalta asioista, jotka tuli ratkaista valtakunnallisesti. ${ }^{156}$ Vuoden 1905 marraskuun manifesti kuitenkin pysäytti helmikuun manifestin soveltamisen ja kumosi myös muuta niin sanotun ensimmäisen sortokauden sääntelyä. Otteen jälleen tiukennuttua annettiin vuonna 1910 laki, jossa listattiin valtakunnalliseen lainsäätämisjärjestykseen kuuluvat asiat. Paikalliseen lainsäädäntöön nähden ehdottomalla etusijalla olevaan valtakunnalliseen lainsäädäntöön kuuluivat muun muassa ulkomaalaisten oikeudet Suomessa, kansainvälinen liikenne, tullilaitos, tullitariffit, posti ja puhelin sekä painotuotteiden maahantuonti ulkomailta ${ }^{157}$ - kaikki tärkeitä pohjoisen rajaseudun kannalta.

Ensimmäisen maailmansodan aikana ulkomaanmatkailua rajoitettiin. Maaliskuun 1916 asetuksella kiellettiin antamasta ulkomaanpassia henkilöille, joiden matkaa kenraalikuvernööri piti vahingollisena. Ulkomaanpassi annettiin vain yhtä matkaa varten kerrallaan, paitsi täysin luotettaville henkilöille, jotka kaupan, elinkeinon tai muun toimen vuoksi olivat monikertapassin tarpeessa. ${ }^{158}$ Rajaseutupoikkeuksia ei mainittu, mutta epäilemättä rajaseudulla oli paljon väestöä, jonka matkustaminen Ruotsiin täytti poikkeusperusteen soveltamisedellytykset. Suuriruhtinaskunnan viimeisen senaatin vuonna 1917 antamassa päätöksessä puolestaan tähdättiin voimassa olleiden passiasetusten parempaan noudattamiseen. Päätöksessä säädettiin sakolla rangaistavaksi passitta tai muuten salaisesti ulkomaille matkustaminen sekä sellaisen avustaminen. Rajaseudun poikkeuksia ei taaskaan mainittu. ${ }^{159}$

Tilanteen kiristyminen heijastui myös pohjoisen länsirajan valvontaan. Kun Ruotsin vastaisella rajalla oli vuosisadan vaihteessa 17 tullivalvojaa, oli heitä vuodesta 1911 lähtien 39 ja vuonna 1916 jo 102. 
Perinteisen salakuljetuksen lisäksi pyrittiin torjumaan myös poliittista salakuljetusta. ${ }^{160}$ Resurssien lisääminen oli perusteltua, koska rajaseutu oli vastarintatoiminnalle otollista. Haaparannalta salakuljetettiin kiellettyä kirjallisuutta sekä pidettiin vuonna 1903 Suomen asevelvollisuuskutsuntojen vastustamiskokous. ${ }^{161}$ Myös Ruotsin rajahenkilöstöä lisättiin huomattavasti maailmansodan sytyttyä. ${ }^{162}$

Keski-Euroopassa puhjennut sota ei merkinnyt sotajoukkojen keskittämistä pohjoiseen. Päinvastoin Ruotsin puolueettomuusjulistuksen myötä Venäjä siirsi joukkojaan Suomesta. Venäjän huollolle rajan häiriötön toiminta oli tärkeää, eikä se halunnut provosoida Ruotsia. Ruotsin sotilasjohto sai puolestaan luotettavilta lähteiltä Suomesta ajantasaista tietoa Venäjän toimista ja pystyi mitoittamaan joukkonsa rajalla maltillisiksi. Saksalaiset, jotka olivat elätelleet toiveita Ruotsin liittymiseen sotaan puolelleen, olivat tyytymättömiä. ${ }^{163}$ Raja-alueelle ja sen väestölle oli onni, ettei alueesta tullut taistelukenttää.

Venäjän salaista poliisia edustaneet santarmit saapuivat Tornioon vuonna $1900 .{ }^{164}$ Santarmien salainen toiminta ulottui myös Haaparannan puolelle ja tehtävänä oli muun muassa ottaa selvää kirjapainotoiminnasta. Saksan maihinnousua pelänneet venäläiset perustivat länsirajaa valvomaan vuonna 1915 venäläisistä koostuneen Suomenmaalaisen Rajavartioston, jonka tehtäviin kuului rajatarkastusten lisäksi estää salakuljetusta ja vastavakoilutoimintaa. ${ }^{165}$ Vuonna 1917 länsirajalle oli sijoitettuna yli tuhat venäläissotilasta. ${ }^{160}$

Poliittinen ja sotilaallinen kehitys hankaloitti helppoon rajan ylittämiseen tottuneiden paikallisten elämää. Tullihallitus määräsi vuonna 1903 Tornioon rakennettavaksi aidan, joka sulki jokirantaan menevät poikkikadut ja joen ylittävään kävelysiltaan rakennutettiin vartioitu portti. Lopulta kulku Torniosta Haaparantaan tai päinvastoin kiellettiin kaikilta, joilla ei ollut ylittämiseen oikeuttavaa Tornion poliisimestarin tai Haaparannan nimismiehen antamaa passia. Rajanylitysmääräykset kuitenkin lievenivät pian ja vuoden 1905 suurlakon yhteydessä kaupunkilaiset kaatoivat portin. ${ }^{167}$

Toisen sortokauden myötä rajakontrolli jälleen kiristyi. Vuonna 1913 rajan yli kulkeminen ilman passia kiellettiin kokonaan. Passipakosta seurasi vaikeuksia, joten rajaseudun väestö molemmin puolin vapautettiin siitä: passia edellytettiin vain tullimiehille tuntemattomilta henkilöiltä. ${ }^{168}$ Sen sijaan paikallisiakin koskivat uudet määräykset, jotka tekivät rajanylityksen sallituksi vain tietyistä ylikulkupaikoista. ${ }^{169} \mathrm{Ra}$ jakäytännöt ovat esimerkki siitä, että myös autonomian loppuaikoina rajaseudun erityisolosuhteet tunnistettiin ja jossain määrin myös huomioitiin. Kuten aiemmin esitetty, valtiollisessa sääntelyssä raja-alueen asukkaille ei ollut myönnetty täyttä liikkumisvapautta vaan vain eräitä helpotuksia. Ilmeisesti paikallisesti lievennyksiä tulkittiin usein laventavasti ja käytännössä liikkumisen kontrollointi näytti olleen löyhää harvoja poikkeusaikoja lukuun ottamatta.

Myös Suomi julistettiin sotatilaan heinäkuun lopussa 1914. Ruotsin hallitus määräsi aluksi maahantulokiellon venäläisten lisäksi myös suomalaisille. Paikkakuntalaiset saivat kuitenkin pian Haaparannan poliisimestarin antamalla todistuksella oikeuden rajanylitykseen. Jo elokuun lopulla Ruotsi peruutti suomalaisten ja venäläisten yleisen oleskelukieltomääräyksen. ${ }^{170}$ Saksa kykeni estämään merikuljetukset Itämeren kautta, joten Krimin sodan aikojen tavoin lännen ja idän välistä liikennettä ja esimerkiksi postia siirtyi kulkemaan pohjoista reittiä. Puolueettoman Ruotsin läpi kulki myös valtavasti pakolaisia sekä haavoittuneita. $^{171}$

Koska Muurmannin rata rakennettiin vasta sotavuosien aikana, oli luoteinen huoltoyhteys Venäjälle tärkeä. ${ }^{172}$ Saksan vaatimuksesta Ruotsi kuitenkin kielsi tammikuussa 1915 sodankäyntiin välittömästi liittyvien tarvikkeiden kuljetukset alueensa läpi. ${ }^{173}$ Tästä syystä sotatarvikkeita alettiin kuljettaa vaivalloista reittiä Pohjois-Norjan kautta Suomen puolta etelään. Reitin merkitys jäi Venäjän kokonaishuollon kannalta vähäiseksi, mutta toi tilapäisesti rajaseudun suomalaisille hyväpalkkaista työtä. ${ }^{174}$

Sodan pitkittyessä kaupankäynti väheni, salakuljetus lisääntyi ja rajan yli kulki myös vakoojia. Suurin osa Saksaan jääkärikoulutettavaksi menneistä ylitti niin ikään rajan Torniosta, tosin usein avoimesti 
vetoamalla esimerkiksi opinto- tai liikeasioihin. Ylittämistä helpottivat jääkäriliikkeelle myötämieliset poliisi- ja tullimiehet. ${ }^{175}$ Jääkäreiden vastaanottoasema sijaitsi Haaparannan puolella ja auttoi suomalaisia eteenpäin. $^{176}$

Erikoinen vaiheensa oli vuoden 1915 kevätkausi, jolloin rajaliikenne oli siirtynyt Karunkiin, minne Ruotsin junarata oli valmistunut. Ruotsalaiset olivat halunneet päättää radan sisämaahan, tykkien kantaman ulottumattomiin. Suomen puolen rata Torniosta Karunkiin rakennettiin ennätysvauhtia ja perustettiin tullikamari. ${ }^{177}$ Rajan pystyi ylittämään vain Karungista, mutta paikalliset saivat käyttää Tornion ja Haaparannan välistä puusiltaa. ${ }^{178}$ Kiireessä routamaahan rakennettu rata sekä maantie Karunkiin menivät kuitenkin pian liikennekelvottomiksi ja rajaliikenne palautui Tornioon ruotsalaisten rataosuuden valmistuttua Haaparantaan alkukesällä $1915 .{ }^{179}$ Logistiset tarpeet peittosivat sotilaalliset uhkakuvat.

\section{Itäpuoli itsenäiseksi}

Nikolai II luopui kruunusta maaliskuussa 1917, eikä Suomella ollut suuriruhtinasta. Venäjän duuma asetti uuden hallituksen, jonka oli määrä hoitaa asioita perustuslakia säätävään kokoukseen asti. ${ }^{180}$ Väliaikainen hallitus antoi maaliskuun manifestin, jolla muun muassa kumottiin helmikuun 1899 manifestin perussäännökset (ei itse manifestia) sekä vuoden 1910 yleisvaltakunnallista lainsäädäntöä koskenut laki. ${ }^{181}$ Suomessa heräsi kiivas kiistely siitä, missä olivat Suomen oman vallan rajat ja kenelle valta kuului. ${ }^{182}$

Tsaarinvallan kukistumista juhlittiin myös Torniossa ja kaupunginvaltuusto lähetti duumalle onnittelusähkeen. Tornion työväenyhdistys järjestäytyi työväenneuvostoksi ja otti tehtäväkseen valvoa työväestön etuja sekä toimia järjestyksenvalvojana. Maaliskuun vallankumouksen jälkeen raja toimi: venäläiset sotilaat tarkastivat passit ja suomalaisviranomaiset tavarat. Huhtikuussa työväenneuvosto ja sotilaat päättivät, että vastaisuudessa neuvosto päättäisi passien myöntämisestä, eikä rajan yli päässyt ilman työväenneuvoston leimaa. Kesään mennessä tehtävät palautuivat takaisin viranomaisille. ${ }^{183}$ Ruotsin puolella koettiin silti ongelmaksi, että venäläiset sotilaat käyttäytyivät rajalla mielivaltaisesti ja väkivaltaisesti myös Ruotsin kansalaisia kohtaan. ${ }^{184}$

Venäjän bolševikkivallankumouksen jälkeen Suomessa levisi suurlakko, joka ulottui Tornioon 15. marraskuuta. Työväenneuvosto otti jälleen vallan. Rajan yli pääsi vain sen luvalla ja työväen järjestyskaarti tarkasti passit. ${ }^{185}$ Venäläissotilaat pitivät passien myöntämistä liian löyhäkätisenä ja ottivat passintarkastuksen haltuunsa, vaikka Suomi oli julistautunut itsenäiseksi ja Venäjän uusi hallitus tämän tunnustanut. Tammikuun 1918 lopulla venäläiset luovuttivat kuitenkin vapaaehtoisesti passien ja matkatavaroiden tarkastuksen suomalaisille, paitsi toisten venäläisten ja muiden ulkomaalaisten osalta. ${ }^{186}$ Suomen tosiasiallisen sisäisen ja ulkoisen valtiosuvereniteetin kannalta tilanne pohjoisella länsirajalla oli siten sekava.

Suomen tilanteen riistäydyttyä sodaksi ruotsalaiset sulkivat rajansa: maahan pääsi ainoastaan Haaparannan poliisimestarin lupakortilla. ${ }^{187}$ Torniossa venäläisten aseistariisuntaa ryhdyttiin toimeenpanemaan valkoisten apujoukkojen saavuttua. Kaikki venäläiset eivät antautuneet ja vastarintaa tehneet lyötiin lyhyessä taistelussa. Osa venäläisistä pakeni Ruotsiin. Suomalaiset punaiset eivät osallistuneet taisteluihin muun muassa puutteellisen aseistuksen vuoksi. Tilanne Torniossa ja sen lähiseudulla rauhoittui nopeasti, mutta liikkumista ja liikenneyhteyksiä valvottiin tarkasti. ${ }^{188}$ Muualta pohjoiselta raja-alueelta venäläiset poistuivat rauhanomaisesti. ${ }^{189}$

Valkoinen Vaasan senaatti piti länsirajan sotilaallista turvaamista tärkeänä. Itsenäisen Suomen ensimmäinen rajavartiosto asetettiin Tornioon 5. maaliskuuta ja miehistö koottiin muista kuin salakuljetukseen taipuvaisista paikallisista. ${ }^{190}$ Salakuljetuksen lisäksi haluttiin estää kommunistisen propagandamateriaalin tuontia ja Ruotsiin paenneiden punaisten salaista maahantuloa. ${ }^{191}$ Suomen itsenäistymisen myötä 
Ruotsi ryhtyi vähentämään rajahenkilökuntaansa ja päätti sotilaallisen valmiuden ylläpitämisen joulukuussa 1918. Suomesta paenneet punaiset herättivät kuitenkin vallankumouspelkoa myös ruotsalaisviranomaisissa. ${ }^{192}$ Pohjoisen länsirajan lopulta melko vähin inhimillisin ja aineellisin vahingoin tapahtunut vakautuminen edesauttoi osaltaan sitä, että toimintaa rajan yli pystyttiin jatkamaan myös valtiollisesti muuttuneessa tilanteessa.

Ruotsin itäinen rajanaapuri ei ollut enää keisarillinen Venäjä vaan itsenäinen Suomi. Pohjoinen länsiraja pysyi edelleen keskusvallan kannalta tärkeänä alueena ja sen omalakisuuteen taipuvainen väestö epäilyksiä herättävänä - vallanpitäjät olivat vain vaihtuneet.

\section{Lopuksi}

Suomen ja Ruotsin pohjoinen raja syntyi eurooppalaisen suurvaltapolitiikan sivutuotteena. Historiallisesti yhtenäinen alue väestöineen tuli kuulumaan kahteen eri valtakuntaan ja oikeusjärjestykseen, vaikka Ruotsin lait jatkoivat voimassaoloaan Suomessa. Itäpuolen asukkaista tuli Venäjän alamaisia, mutta yhteiskunnallisen ja oikeudellisen yhteyden katkeamattomuus mahdollisti elämän jatkumisen monilta osin ennallaan.

Vanhoja siteitä pyrittiin valtiojohtoisesti katkomaan ja tekemään rajasta ihmisiä niin oikeudellisesti kuin henkisesti erotteleva. Vuosisadalle tyypilliset modernisaatio- ja kansallisvaltioprojektit pyrkivät integroimaan pohjoisen rajaseudun tiiviimmin omaan valtioon ja kansaan. Tarve tietoiseen kielellisen ja henkisen rajan rakentamiseen oli Ruotsilla, jossa rajaseudun suomalaisväestön ruotsalaistamista pidettiin valtiollisena turvallisuuskysymyksenä. Pohjoisen periferian strateginen merkitys kasvoi, kun se yhdistettiin tiiviimmin uusiin liikenne- ja viestintäverkkoihin.

Silti Haminan rauhansopimuksesta lähtien Venäjän ja Ruotsin välisissä virallisissa suhteissa paikalliset erityistarpeet rajan ylittävään liikkumiseen ja elinkeinonharjoittamiseen otettiin yllättävän kattavasti huomioon. Rajan valvontaa tehostettiin molemmin puolin erityisesti kaupallisten etujen valvomiseksi, ei niinkään paikallisväestön kontrolloimiseksi. Rajaseuduille tyypillisesti valtakunnallista sääntelyä, kuten tullisäännöksiä, kierrettiin paikallisesti surutta. Valtiollisen tason toimista riippumatta myös paikalliset yhteydet rajan yli jatkuivat tiiviinä.

Niin sanotut venäläistämiskaudet ja ensimmäinen maailmansota vaikuttivat myös pohjoisen länsirajan elämään. Rajavalvontaviranomaisten ja sotilaiden määrä kasvoi samalla kun rajanylittämissäännöt ja -käytännöt olivat tempoilevia. Ei ole ainutlaatuista, että suuret yhteiskunnalliset ja poliittiset tapahtumat heijastuvat raja-alueille. Pohjoisesta rajaseudusta ei silti onneksi tullut maailmansodan taistelutannerta.

Venäjän keisarikunnan lopullisesta luhistumisesta ja Suomen sisäisestä myllerryksestä selvittiin länsirajalla kuitenkin lopulta varsin vähin vaurioin, vaikka tilanne oli ajoittain sekava. Keväästä 1918 lähtien raja oli itsenäisen Suomen viranomaisten hallussa. Ylimmän valtiollisen vallan pitäjät jälleen vaihtuivat, mutta yhteydet rajan yli jatkuivat.

Pohjoisen länsirajan historia vuodesta 1809 alkaen antaa tietoa siitä, miten tilannesidonnaisesta ja paikallisväestöstä riippumattomasta rajan vetämisestä voi seurata nykypäivänäkin havaittavia yhteiskunnallisia, oikeudellisia ja kulttuurisia vaikutuksia. Vaikka raja on aluksi vain tekstiä sopimuspaperissa, se konkretisoidaan toiminnalla. Raja ei synny, se rakentuu. Silti tapahtui myös paljon paikalliseen elämänmuotoon kuuluvaa rajattomuutta ylläpitävää toimintaa, joten historian kaari ei ole yksioikoinen. Kyse on moniulotteisesta prosessista, jossa rajan itäpuolen muuttuminen itsenäiseksi Suomeksi on yksi tapahtuma, ei siihenastisen historian päämäärä. 


\begin{abstract}
${ }^{1}$ Norrbottenin läänin maaherran Ragnar Lassinantin (1915-1985) toteamus. Raja 200 - Gränsen 200. Tornionlaakson vuosikirja. Tornedalens airsbok 2008-2010, esipuhe. Tornionlaakson neuvosto, Tornionlaakson maakuntamuseo, 2010, 6.
\end{abstract}

2 Esim. Korona turhauttaa ja hämmentää raja-alueiden asukkaita. Tiedote 2.7.2020, Pohjola-Norden. Katsottu Url: https://www.norden.org/fi/uutinen/korona-turhauttaa-ja-hammentaa-raja-alueiden-asukkaita. Katsottu 13.8.2021.

${ }^{3}$ Vrt. Heikki Ylikangas. Oikeus bistoriallisena ilmiönä. Suomen Lakimiesliiton kustannus Oy, Helsinki 1976, 8; Jukka Kekkonen. "Oikeudellisen muutoksen tutkimuksesta - minun metodini”. Minun metodini (toim. Juha Häyhä), Werner Söderström Lakitieto Oy, Helsinki 1997, 131-151, 142-143; Heikki Ylikangas. Mitä on historia ja millaista sen tutkiminen. Art House, Helsinki $2015,35$. ${ }^{4}$ Hans-Georg Gadamer. Hermeneutiikkea. Ymmärtäminen tieteissä ja filosofiassa. Valikoinut ja suomentanut Ismo Nikander. Vastapaino, Tampere, 2004, 207-211.

${ }^{5}$ Ks. Henrik Wenander. Fri rörlighet i Norden. Nordiska gränshinder i rättslig belysning. Skrifter utgivna vid Juridiska Fakulteten $\mathrm{i}$ Lund Nr 179. Acta Societatis Juridicae Lundensis, Lund, 2014, 15; Matti Niemivuo. "Har Sveriges förvaltningslag påverkat Finlands motsvarande lag - eller tvärtom?" Förvaltnigsrättslig Tidskrift vol. 81, 3/2018, 623-642, 641.

${ }^{6}$ Ks. Mikko Majander. Komplekseja, kilpailua ja kumppanuutta Suomen ja Ruotsin subteissa. Siltala, Helsinki 2020, 185.

${ }^{7}$ Ks. Osmo Jussila. Suomen suurirubtinaskunta 1809-1917. WSOY, Helsinki, 2004, 12.

${ }^{8}$ Maantieteellisenä alueena Tornionlaakso muodostuu suhteesta Tornionjokeen ja siihen laskevaan Muonionjokeen asettuen näiden jokien varsille niiden molemmin puolin. Ks. Jari Koivumaa. Geopoliittista kuvittelua Pobjois-Suomen raja-alueilla. Tutkimus perifeerisyyden purkamisesta kylmän sodan jälkeisessä kansainvälisessä järjestelmässä 1995-2004. Lapin yliopisto, Rovaniemi, $2008,157$. ${ }^{9}$ Ks. Ilkka Teerijoki. Tornion historia 3 1918-2000. Tornion kaupunki, Tornio, 2010, 393.

${ }^{10}$ Esim. Maria Lähteenmäki. Kalotin kansaa. Rajankäynnit ja vuorovaikutus Pobjoiskalotilla 1808-1889. Suomalaisen Kirjallisuuden Seura, Helsinki, 2004, 346-383; Matti Enbuske. Lapinmaan maaoikeudet. Asutus ja maankäyttö keskisessä Lapissa ja Enontekiöllä 1900-luvun alkunn. Oikeusministeriön julkaisuja 2006:6.

${ }^{11}$ Ilkka Teerijoki. Tornion historia 2 1809-1918, Tornion kaupunki, Tornio, 2007, 16-21; Nils Slunga. Gränsen mot Finland. En ovanlig gräns. Haparanda, 1959, 9-10; Sten Wikström. Norrbotten - en studie om gränser. Tornedalica nr. 38. Luleå. 1982, 67-69; Lars Elenius. Nationalstat och minoritetspolitik. Samer och finskspräkiga minoriteter i ett jämförande nordisk.t perspektiv. Studentlitteratur, Lund, 2006, 30.

12 Antti Paasi. Territories, Boundaries and Consciousness. The Changing Geographies of the Finnish-Russian border. John Wiley \& Sons, Chichester, 1996, xix, 4, 82.

${ }^{13}$ Ks. Osmo Jussila. Maakunnasta valtioksi. Suomen valtion synty. WSOY, Helsinki, 1987, 22, 88. Jussila toteaa, että Venäjän lisäksi myös Ruotsilla oli monivaltioinen ja monikansallinen valtakuntaluonne. Jussilan mukaan 1800-luvun alun suomen kielessä ei vielä ollut lainkaan sanaa valtio: se kehitettiin ja otettiin vaihtelevalla menestyksellä käyttöön 1800-luvun puolivälistä lähtien.

${ }^{14}$ Gabriel Bladh \& Christer Kuvaja. "Yhdestä valtakunnasta kahdeksi kansallisvaltioksi”. Kabden puolen Pobjanlabtea I. Ihmisiä ybteisöjä ja aatteita Ruotsissa ja Suomessa 1500-luvulta 1900-luvulle. Suomalaisen Kirjallisuuden Seura, Helsinki, 2006, 35; EevaKaisa Prokkola. "Rajayhteistyö, alueellistuminen ja identiteetti Tornionlaaksossa." Raja 200 - Gränsen 200. Tornionlaakson vuosikirja. Tornedalens arrsbok 2008-2010. Tornionlaakson neuvosto, Tornionlaakson maakuntamuseo, 2010, 379-396, 379; EevaKaisa Prokkola. Making bridges, removing barriers. Cross-border cooperation, regionalization and identity at the Finnish-Swedish border. Nordia Geographical Publications 37:3, Oulu, 2008, 9.

${ }^{17}$ Ks. Gabriel Bladh \& Christer Kuvaja. Esipuhe teoksessa Kabden puolen Pohjanlabtea I. Ibmisiä ybteisöjä ja aatteita Ruotsissa ja Suomessa 1500-luvulta 1900-luvulle. Suomalaisen Kirjallisuuden Seura, Helsinki, 2006.

${ }_{18}^{18}$ Maria Lähteenmäki. Jälkiä lumessa. Arktisen Suomen pitkä historia. Valtioneuvoston kanslian julkaisuja 8/2017, 131.

${ }^{19}$ Lassi Heininen. "Pohjoinen geopoliittinen alue." Maa, seutu, kulmakunta. Näkökulmia aluebistorialliseen tutkimukseen. Toim. Maria Lähteenmäki. Suomalaisen Kirjallisuuden Seura, Helsinki, 2009, 150-169, 155; ks. myös Karl Nickul. Saamelaiset kansana ja kansalaisina. Suomalaisen Kirjallisuuden Seuran toimituksia 297. Helsinki, 1970, 196-205.

20 Päiviö Tommila. Suomen autonomian synty 1808-1819. 2. uudistettu painos. Edita, Helsinki, 2008, 94.

${ }^{21}$ Teerijoki 2007, 13; Jyrki Paasikoski. "Miksi Venäjä halusi valloittaa ja pitää Suomen? - Venäjä ja Ruotsi Itämeren piirissä 1700-1815." Raja 200 - Gränsen 200. Tornionlaakson vuosikirja. Tornedalens årsbok 2008-2010. Tornionlaakson neuvosto, Tornionlaakson maakuntamuseo, 2010, 11-29, 25.

22 Åke Gustafsson. Riksgräns historia \& gränsöversyner. Från Svinesund till Haparanda. Lantmäteriet Kartförlaget. Gävle, $1995,74$. ${ }^{23}$ Syväväyläperiaate oli vastikään syrjäyttänyt keskiviivaperiaatteen mannereurooppalaisissa jokirajasopimuksissa. Ks. Kyösti Haataja. "Valtakunnan rajankäynnissä Pohjanlahdesta Jäämereen esiintyneitä oikeudellisia kysymyksiä." Maanmittaus. 2. vuosikerta. 1927, 4.

${ }^{24}$ Haminan rauhansopimus, art. V. Ks. suomenkielinen käännös mm. Tornion-ja Muonionjokien sekä Könkämäenon suvereniteettisaaret. Suomalais-ruotsalaisen selvityksen suvereniteettimietintö. Nordisk utredningsserie 1975:27, 49; syväväylään liittyvistä tulkintakysymyksistä ks. Erkki Hollo. "Suomen ja Ruotsin välisten saariomistusten asema raja-asiakirjojen valossa. Lakimies 72.1974 , 433-451,435-436.

${ }^{25}$ Ilkka Mäntylä. Tornion historia. 1. osa 1621-1809, Tornion kaupunki, Tornio, 1971, 13, 24-25; Lars Elenius. "Identiteter i Tornedalen". Raja 200 - Gränsen 200. Tornionlaakson vuosikirja. Tornedalens ärsbok. 2008-2010. Tornionlaakson neuvosto, Tornionlaakson maakuntamuseo, 2010, 329-354, 331.

${ }^{26}$ Jussila 2009, 11-13; Tommila 2008, 12-16, Mäntylä 232-233.

27 Tommila 2008, 46.

28 Teerijoki 2007, 16-21; Mäntyä 1971, 523, Paasikoski 2010, 25; Elenius 2010, 336; Jouko Vahtola. "Suomen sota antoi uuden suunnan Suomelle ja Torniolle". Raja 200 - Gränsen 200. Tornionlaakson vuosikirja. Tornedalens ärsbok. 2008-2010. Tornionlaakson 
neuvosto, Tornionlaakson maakuntamuseo, 2010, 66-81, 72; Christer Kuvaja. "Språkgränsen i Västerbotten i slutet av svenska tiden". ". Raja 200 - Gränsen 200. Tornionlaakson vnosikirja. Tornedalens årsbok. 2008-2010. Tornionlaakson neuvosto, Tornionlaakson maakuntamuseo, 2010, 354-377, 358.; Kustaa Vilkuna. "Kemin-Kaakaman nautintarajan sijainti ja kansatieteellinen tausta". Kalevalaseuran vuosikirja 29. WSOY. Porvoo, Helsinki. 1949, 343-400, 343, 348.

${ }^{29}$ Hannu Heinänen. "Haminan rauha ja toimeentulon turvaaminen paikalliselle väestölle." Raja 200 - Gränsen 200. Tornionlaakson vuosikirja. Tornedalens årsbok 2008-2010. Tornionlaakson neuvosto, Tornionlaakson maakuntamuseo, 2010, 114-158, 125; rajanjärjestelysopimusprosessista ks. Erkki K. Osmonsalo. Suomen rajapolitiikkea Venäjän vallan aikana. Osa 1: Ruotsin vastaista rajaa koskevat kysymykset 1809-1924. Suomen Historiallinen Seura, Helsinki, 1933, 54-132; Ks. Rajanjärjestelysopimuksen teksti: Suomen-Ruotsin rajankäynti. Suomen ja Ruotsin rajankäyntivaltuuskunnat, 2006, 3-6.

30 Tommila 2008, 17-19; Sam Clason. Gustaf IV Adolf och den europeiska krisen under Napoleon. Hugo Gebers Förlag. Stockholm. 1913, 157-158; Krister Wahlbäck. Jättiläisen henkäys. Suomen-kysymys Ruotsin politiikassa 1809-2009. Kustannusosakeyhtiö Siltala, Helsinki, 2020, 20-22; Paasikoski 2010, 11, 15; Tommila 2008 121-122; Torkel Jansson. "Kahdesta valtakunnasta viisi kansallisvaltiota - ja vielä useampi kansakunta". Pobjoismaiden historia 1397-1997. 10 esseetä. Toim. Henrik S. Nissen. Yle, Pohjoismaiden ministerineuvosto. Helsinki, Kööpenhamina, 1997, 65-98, 76.

31 Maria Lähteenmäki. "Suomen Lapin synty ja Tornionlaakso 1809-1889." Raja 200 - Gränsen 200. Tornionlaakson vuosikirja. Tornedalens årsbok 2008-2010. Tornionlaakson neuvosto, Tornionlaakson maakuntamuseo, 2010, 96-114, 96-97; Maria Lähteenmäki. Terra Ultima. Matka Lapin historiaan. Otava, Helsinki, 2006a, 34.

32 Lähteenmäki, 2004, 10.

33 Kuvaja 2010, 370; Maria Lähteenmäki. The Peoples of Lapland. Boundary Demarcations and Interaction in the North Calotte From 1808 to 1889. Finnish Academy of Science and Letters, Helsinki, 2006b, 35, 65; Lars Elenius, Maria Lähteenmäki, Jens Petter Nielsen, Alexandr Pashkov. "Transformation of Borders, Economic Systems and Communities 1809-1905". The Barents Region. A Transnational History of Subarctic Northern Europe. Toim. Lars Elenius et al. Pax Forlag As, Oslo 2015, 146-235, 154.

34 Bladh \& Kuvaja 2006, 32; Vahtola 2010, 76; Lähteenmäki 2004, 80.

35 Teerijoki 2007, 44.

${ }^{36}$ Ks. Lars Björne. Oikeusjärjestelmän kehitykesestä. Lakimiesliiton kustannus, Helsinki, 1986, 10-15; ks. hallinnollisten olojen pääpiirteistä autonomian ajalla K. J. Ståhlberg. Suomen-hallinto-oikeus. Yleinen osa. 2., uudistettu painos. Otava, Helsinki, 1928, 22-36; ks. pohjoismaisen oikeudellisen ajattelun jatkuvuudesta Pia Letto-Vanamo; Ditlev Tamm. "Nordic legal mind". Nordic Law in European Context. Toim. Pia Letto-Vanamo; Ditlev Tamm, Bengt Ole Gram Mortensen. Springer. 2019, 1-19 .

${ }^{37}$ Ks. Rafael Erich. Suomen valtio-oikeus. I osa. Tietosanakirja-osakeyhtiö. Helsinki, 1924, 50; Osmonsalo $1933,1$.

38 Yrjö Blomstedt. "Suomi Venäjän yhteydessä". Suomen oikeus ja yhteiskuntajärjestys. Toim. Inkeri Anttila \& al. Suomalaisen Lakimiesyhdistyksen julkaisuja. B-sarja N:o 7. WSOY, Helsinki, 1974, 114-133, 117.

${ }^{39}$ Keijo Korhonen. Suomen asiain komitea. Suomen korkeimman hallinnon järjestelyt ja toteuttaminen vuosina 1811-1926. Suomen Historiallinen Seura, Helsinki, 1963, 238.

${ }^{40}$ Laura Ervo. Comparative Analysis between East-Scandinavian Countries. Scandinavian studies in law. Stockholm Institute for Scandinavian Law, 2015, 135-152, 137; Tommila 2008, 103.

41 Osmo Jussila. "Suomi suuriruhtinaskuntana 1809-1917". Suomen poliittinen historia 1809-2009, 9-100. Osmo Jussila, Seppo Hentilä, Jukka Nevakivi. WSOY Oppimateriaalit Oy, Helsinki 2009, 15-18; Jussila 1987, 25-28.

${ }^{42}$ Tommila 2008, 105-106; Osmo Jussila. Suomen perustuslait venäläisten ja suomalaisten tulkintojen mukaan 1808-1863. Historiallisia tutkimuksia LXXVII. Suomen Historiallinen Seura, Helsinki, 1969, 78.

${ }^{43}$ Osmo Jussila. Suomen perustuslait venäläisten ja suomalaisten tulkintojen mukaan 1808-1863. Suomen Historiallinen Seura. Helsinki. 1969, 38-41; Korhonen 1963, 20, 28; Soikkanen 2009, 13-17; Rasilainen 2009a, 262-263; ks. Erich $192443-44$ tulkinnasta, jonka mukaan Suomen ja Venäjän välillä syntyi Porvoossa kaksipuolisesti velvoittava oikeustoimi.

${ }^{44}$ Aki Rasilainen. "Kustavilaisten perustuslakien voimassaolo autonomian aikana". Taistelu autonomiasta. Perustuslait vai itsevaltius? Edita Publishing Oy. Helsinki, 2009a, 252-278, 252.

45 Herman Lindqvist. Ruotsin historia. Jä̈kaudesta tulevaisunteen. WSOY. Helsinki, 2003, 567-568.

${ }^{46}$ Max Engman. Pitkät jäähyväiset. Suomi Ruotsin ja Venäjän välissä 1809 jälkeen. WSOY. Helsinki, 2009, 92-93, 95; Timo Soikkanen. "...Lakiensa suojeluksessa". Taistelu autonomiasta. Perustuslait vai itsevaltius? Edita Publishing Oy. Helsinki, 2009, 13-87, 14; ks. Soikkanen 2009 myös valtiopäivät-maapäivät -semantiikasta 59-62.

${ }^{47}$ Pia Letto-Vanamo \& Ditlev Tamm. "Nordic Legal Mind". Nordic Law in European Context. Toim. Pia Letto-Vanamo, Ditlev Tamm, Bent Ole Gram Mortensen. Springer. Cham, 2019, 1-19.

${ }^{48}$ Elenius 2010, 337-338; Wahlbäck 2020, 88; Elenius. 2006, 103; Elenius, Lähteenmäki, Nielsen \& Pashkov 2015,216

${ }^{49}$ Elenius 2006, 103.

50 Wahlbäck 2020, 88, 106.

${ }^{51}$ Daniel Nilsson Ranta. Nödhjälp på villovägar: implementering av en filantropisk välfärdsidé. Norrbottens arbetsstugor 1903 - 1954. Umeå universitet, Umeå, 2008, 35; Elenius 2010, 339.

52 Wahlbäck 2020, 88.

${ }^{53}$ Lars Elenius. Både finsk och svensk. Modernisering, nationalism och språkförändring i Tornedalen 1850-1939. Umeå universitetet. Umeå, 2001, 396-398.

${ }^{54}$ Elenius 2010, 338; Wahlbäck 2020, 88; Tommila 2008, 126; Harald Gustafsson. “Keskusta ja äärialueet”. Pobjoismaiden historia 1397-1997. 10 esseetä. Toim. Henrik S. Nissen. Yle, Pohjoismaiden ministerineuvosto, Helsinki, Kööpenhamina, 1997, 125$154,140$.

55 Elenius 2001, 407; Elenius 2006, 86; Paasi 1996, 60. 
${ }^{56}$ Oscar J. Martinez. "The dynamics of border interaction: New approaches to border analysis". C.H. Schofield (toim.). Global Boundaries. World Boundaries Volume 1. Routledge, New York, 1994, 1-15, 11.

57 Tommila 2008, 96.

58 Teerijoki 2007, 24. Ks artiklan teksti Tornion- ja Muonionjokien sekä Könkämäenon suvereniteettisaaret. Suomalais-ruotsalaisen selvitykesen suvereniteettimietintö. Nordisk utredningsserie, 1975:27, 54.

${ }^{59}$ Nordisk utredningsserie 1975:27, 20, 54.

${ }^{60}$ Eric Anthoni. De västerbottniska områdenas förening med Finland. Historisk tidskrift för Finland 1922. Årgång 7. Helsinki, 1922, 1-23, 20.

${ }^{61}$ Tommila 2008, 97, Osmonsalo 1933, 116

${ }^{62}$ Hannu Heinänen. "Haminan rauha ja toimeentulon turvaaminen paikalliselle väestölle.” Raja 200 - Gränsen 200. Tornionlaakson vuosikirja. Tornedalens årsbok 2008-2010. Tornionlaakson neuvosto, Tornionlaakson maakuntamuseo, 2010, 114-158, 126-131; Hannu Heinänen. Tornionjokilaakson tilusvaibdot Haminan rauban jälkeen (1809-1824). Suomen historian pro gradu työ. Jyväskylän yliopisto, 1985, 148.

63 Osmonsalo 1933, 347-367, 408.

${ }^{64}$ Osmonsalo 1933, 83; Erkki Harju. "Rajajokien suvereniteettisaarten historiaa ja nykypäivää." Tornionlaakson vuosikirja 1983. Tornionlaakson kotiseututoimikunta. Tornio, 1983, 68-84, 68; Väinö Ahla. "Tornion ja Muonion joissa olevat n. s. suvereniteettisaaret." Maanmittaus. 28:s vuosikerta. 1953, 69-90, 70.

${ }^{65}$ Heinänen 2010; Nordisk utredningsserie 1975:27, 21-22, 33, 54; Gustafsson 1995, 147; Komissaarien pöytäkirja 3.9.1813 siihen sisältyvine kuulutuksineen. Nordisk utredningsserie 1975:27, 64-65.

${ }^{66}$ Nordisk utredningsserie 1975:27, 13, 22; Vähä 1993, 397; Ahla 1953, 82.

${ }^{67}$ Hollo 1974, 444; Haataja 1927, 15-16.

${ }^{68}$ Harju 1983, 76-77; Ahla 1953, 75-76.

${ }^{69}$ Osmonsalo 1933, 182; Heikki Rantatupa. Alatornion historia. Tornion kaupunki, Tornio, 1988, 191.

${ }^{70}$ Heinänen 2010, 120, 122, 134; Osmonsalo 1933, 183; Rantatupa 1993, 202-203.

${ }^{71}$ Eero Vähä. "Katsaus tulevaisuuteen". Tornionlaakson historia II. 1600-luvulta vuoteen 1809. Tornionlaakson kuntien historiakirjatoimikunta, Tornio, 1993, 389-405, 391; Rantatupa 1993, 206.

${ }^{72}$ Ilkka Mäntylä. 'Tornio-kaupunki”. Tornionlaakson historia II. 1600-luvulta vuoteen 1809. Tornionlaakson kuntien historiakirjatoimikunta, Tornio, 1993, 181-263, 262.

73 ks. artiklan teksti Nordisk utredningsserie 1975:27, 50.

${ }^{74} \mathrm{ks}$. artiklan teksti Nordisk utredningsserie 1975:27, 55.

${ }^{75}$ Hederyd 1993, 154-155.

${ }^{76}$ Asetus 1845-10-20. Keisarillisen Majesteetin Armollinen Julistus kuinka 4:nnen artikkelin 1:nen momentti, Wenäjän Keisarillisen waltakunnan ja Ruotsin riikin wälillä 8:ten (20:tenä) p. Marraskuuta 1810 tehdystä raja-regleeringin Suostumuksesta, on ymmärrettävä ja edespäin jälkeenelettävä. (20.10.1845). Keisarillinen Suomen Senaatti, Helsinki, 1845.

${ }_{77}$ Paavo Peura. "Riikinjaosta säännöstelytalouteen - Salakuljetuksen historia Torniossa." Raja 200 - Gränsen 200. Tornionlaakson vuosikirja. Tornedalens årsbok 2008-2010. Tornionlaakson neuvosto, Tornionlaakson maakuntamuseo, Tornio, 2010, 209-256, 213; Teerijoki 2007, 328.

${ }^{78}$ Engman 2009, 149-150.

${ }^{79}$ John Torpey. The Invention of the Passport. Surveillance, Citizenship and the State. Cambridge University Press, 2002, 1-2, 6-7, 159. ${ }^{80}$ Förordning om det, som $\mathrm{i}$ anseende till ankommande utländske Resande till Finland iaktagas bör (23.2.1811). Julkaistu teoksessa Antero Leitzinger. Ulkomaalaiset Suomessa 1812-1972. East-West Books, Helsinki, 2008, 350-351.

${ }^{81}$ Finlands Allmänna Tidning 14.5.1829 no 55, 219; Finlands Allmänna Tidning 5.2.1829 no 13, 51.

${ }^{82}$ Leitzinger 2008, 19.

${ }^{83}$ Leitzinger 2008, 63.

${ }^{84}$ Vrt. Torpey 2002, 76-77.

${ }^{85}$ Leitzinger 2008, 17-19.

86 Asetus passeista sekä Suomen kansalaisille ulkomaalle lähteä, että ulkomaalaisille matkoilla Suomeen ja Suomesta ynnä maassa ollessansa (17.6.1862). Teoksessa Leitzinger 2008, 366-380.

${ }^{87}$ Asetus passeista, sekä Suomen kansalaisille ulkomaalle lähteä että ulkomaalaisille matkoille Suomeen ja Suomessa ynnä siellä oleskellessansa (27.6.1888). Teoksessa Leitzinger 2008, 381-386.

${ }^{88}$ Ks. Einonen, Piia; Frigren, Pirita, Hemminki, Tiina; Uotila, Merja. "Leipä taivalten takana - Liikkuminen 1800-luvun alun Suomessa. Ennen ja nyt: historian tietosanomat 5/2016. URI: http://urn.fi/URN:NBN:fi:jyu-201612205188; Paula Haara; Asko Lehmuskallio. Ruumiin ja dokumenttien kytkökset: Suomen passin historiaa. Suomen valokuvataiteen museon julkaisuja 51, Helsinki, 2020, 13-15; Heikki Ylikangas. "Paikallisen itsehallinnon kehityksestä Suomessa". Suomen oikeushistorian pääpiirteet. Sukuvallasta moderniin oikeuteen. Toim. Pia Letto-Vanamo. Gaudeamus, Helsinki, 1991, 111-128, 125; Lindqvist 2003,623.

${ }^{89}$ Tuomo Polvinen. Die finnischen Eisenbahnen in den militärischen und politischen Plänen Russlands vor dem ersten Weltkrieg. Helsinki. 1962, 10, 276-277; ks. Ruotsin-kysymys Venäjän raidepolitiikassa 261-275.

90 Teerijoki 2007, 334-338; Hederyd 1993, 167. Esimerkiksi Sveitsistä kotimaahansa palannut Vladimir Uljanov saapui Tukholmasta Haaparannan asemalle 15. huhtikuuta 1917. Rajatarkastuksen jälkeen hän jatkoi junalla Torniosta saapuakseen Suomen asemalle Petrogradiin. Ks. Hederyd 1993, 173; Jan Bergsten. Tornedalens järnvägar - en gränslös historia. Trafik-Nostalgiska Förlaget, Stockholm, 2012, 60-62. 
${ }^{91}$ Östen Groth; Gunnar Lassinantti. Nordkalotten - en gränslös utmaning. Skrivarförlaget/Norrbottens bildningsförbund. Luleå 1982; Wahlbäck, 2020, 106; G. W. Lindfors. Karl Gustavs Sockens historia 1543-1934. Bebyggelsen, församlingens tillblivelse och utveckling m. m. Längmanska kulturfonden. Haparanda, 1941, 102-105.

${ }^{92}$ Ks. Ruotsin geopoliittisesta asennoitumisesta Suomen suhteen Matti Roitto; Petri Karonen; Jari Ojala. "Geopolitik och identitet 1890 - 1930". Demokratins drivkrafter. Kontext och särdrag i Finlands och Sveriges demokratier 1890-2020. Toim. Henrik Meinander, Petri Karonen \& Kjell Östberg. Svenska litteratursällskapet i Finland. Helsinfors, 2018, 99-150, 104-106, 110.

${ }^{93}$ Nils Slunga. Staten och den finskspråkiga befolkningen i Norrbotten. Tornedalica. Nummer 3. Luleå, 1965, 105.

${ }_{94}$ Hederyd 1993, 167.

95 Teerijoki 2007, s. 349-350, 352; Hederyd 1993, 156-157; Tommila 2008, 102.

${ }^{96}$ Oiva Turpeinen. "Puhelintoiminnan lainsäädännön synty." Pubelin ja pubelinlaitokset Suomessa 1877-1977, 90-125. U.E. Moisala, Kauko Rahko \& Oiva Turpeinen. Toim. Eino Jutikkala. Puhelinlaitosten liitto, Helsinki, 1977a, 92.

${ }^{97}$ Hederyd 1993, 165-166; Teerijoki 2007, 352; Turpeinen 1877a, 90; Oiva Turpeinen. "Keisarikunnan vaikutus". Pubelin ja puhelinlaitokset Suomessa 1877-1977. U.E. Moisala, Kauko Rahko \& Oiva Turpeinen, 229-282. Toim. Eino Jutikkala. Puhelinlaitosten liitto, Helsinki, 1977b, 229, 231.

98 Turpeinen $1977 \mathrm{~b}, 239$.

99 Turpeinen 1977b, 239-243, Jussila 2014, 719.

100 Martinez 1994, 12-13.

101 Ilkka Teerijoki. Tornion historia 3 1918-2000. Tornion kaupunki, Tornio 2010, 52-53; Kari Filpus. Alkoholin salakuljetus ja sen valvonta Perämeren rannikolla kieltolain aikeana 1919-1932. Oulun yliopisto, Oulu, 2001.

102 Sakari Heikkinen. Suomeen ja maailmalle. Tullilaitoksen historia. Tullihallitus, Helsinki, 1994, 134, 136, 140, 142, 166; Tommila 2008, 102; Jussila 2004, 397. Tullien merkitystä Suomen valtiontaloudelle korosti se, että hallitusmuodon mukaisesti uusia veroja ei saanut määrätä kuin valtiopäivien suostumuksella, joita ei kutsuttu pitkään koolle, ks. Heikkinen 184.

${ }^{103}$ Leo Harmaja. Suomen tullipolitiikeka Venäjän vallan aikana. Edellinen osa: vuoteen 1859. Kansantaloudellinen yhdistys, Helsinki, 1920, 74.

104 Rantatupa 1988, 306.

105 Heikkinen 1994, 150.

106 Heikkinen 1994, 190-193, 289.

${ }^{107}$ Heikkinen 1994, 289; Svanberg 1973, 41.

108 Harmaja 1920, 309.

109 Slunga 1965, 132-133.

110 Ilkka Teerijoki. "Sotalaitos, sodat, sotilaat". Tornionlaakson historia II. 1600-luvulta vuoteen 1809. Tornionlaakson kuntien historiakirjatoimikunta, 1993, 120-142, 142.

111 Slunga 1965, 128-129; Sven Heikkilä. Mitt i Tornedalen - Övertorneå- Polcirkelland. Tornedalens Historia IV. Övertorneå, 1999 , 119.

112 J. Gust. Svanberg. Haparanda 1910-1920. Idyll och dramatik. Tornedalica. Nummer 17. Luleå, 1973, 43

113 Harmaja 1920, 31, 78.

114 Originaltraktater med främmande makter. Ryssland. Fredsfördrag 1809 2:A. SE/RA/25.3./2/44/A/R000419; Harmaja 1920, 49.

115 Originaltraktater med främmande makter. Ryssland. Två separata artiklar till Litt. A. 1812 2:D. SE/RA/25.3/2/47/D; Kauko E. Joustela. Suomen ja Venäjän-kauppa autonomian ajan alkupuoliskolla vv. 1809-65. Suomen Historiallinen Seura, Helsinki, 1963, 33-34, 48.

116 Additionel konvention (No 1) till 1812 års off- och defensivallians. Vilna 15/3 Juni 1812. SE/RA/25.3/2/50/A.

117 Svanberg 1973, 40.

118 Asetus 1845-10-20.

${ }^{119}$ Joustela 1963, 49-50.

120 Joustela 1963, 61, 66, 74; Tarkiainen 1993, 19-20.

121 Teerijoki 2007, 29.

122 Teerijoki 2007, 150.

123 Teerijoki 2007, 21.

124 Teerijoki 2007, 24, 30-32.

${ }^{125}$ Ks. Teerijoki 2007, 208. Torniolainen suurkauppias Anders Kurth (1824-1895) osti sahan Ruotsin Alatorniolta ja ehti pitää sitä hallussaan pitkään, kunnes ruotsalaisviranomaiset havaitsivat, että Kurth ei vierasmaalaisena olisi saanut omistaa sitä. Tilanne ratkesi siirtämällä saha nimellisesti rajan länsipuolisten sukulaisten nimiin.

126 Teerijoki 2007, s. 29-30, 32, 41-42, 156, 166, 193; ks. Pohjois-Kalotin kaupankäyntiä koskevista huolista Ruotsin puolella Olof Hederyd. Haparanda efter 1809. Tornedalens historia III. Birkkarlens förlag, Haparanda, 1993, 46.

127 Teerijoki 2007, 194-195.

${ }^{128}$ Ks. Ruotsin elinkeinovapauslainsäädännöstä Jukka Kekkonen. Merkantilismista liberalismïn. Oikeushistoriallinen tutkimus elinkeinovapauden syntytaustasta Suomessa vuosina 1855-1879. Suomalaisen Lakimiesyhdistyksen julkaisuja. A-sarja N:o 172. Suomalainen Lakimiesyhdistys, Helsinki, 1987, 275-282.

129 Teerijoki 2007, 194.

130 Teerijoki 2007, 256, 261; Pentti Kärki. Tornionlaakson sata säästöpankkivuotta. Rajallinen historiikki Tornionlaakon säästöpankkitoiminnan 100-vuotisjuhlaan, jota vietettiin Ylitorniolla 30.6.1974, 5-6. 
131 Ks. myös Esko Ollila. "Tornionlaakson raja taloudellisen yhteistyön näkökulmasta." Tornionlaakson vuosikirja 1985. Tornionlaakson kotiseututoimikunta. Tornio, 1985, 53-60, 57.

132 Teerijoki 2007, 242,

133 Teerijoki 2007, 448, 452.

134 Ks. Svanberg 1973, 170.

135 Martinez 1994, 12.

136 Teerijoki 2007, 138.

${ }^{137}$ Elenius 2010, 342.

138 Elenius 2010, 337.

${ }^{139}$ Ks. Eric Anthoni. De västerbottniska områdenas förening med Finland. Historisk tidskrift för Finland 1922. Årgång 7. Helsinki, 1922, 1-23, 7-8; Rantatupa 1988, 304.

140 Vahtola 2010, 76.

141 Teerijoki 2007, 496; Slunga 1965, 134-135; Heikkilä 1999, 84; Kuvaja 2010, 365.

142 Vähä 1993, 402.

${ }^{143}$ Kirsti Suolinna. "Den laestadianska väckelserörelsen i Tornedalen.” Studier kring gränsen i Tornedalen. Toim. Elina HaavioMannila \& Kirsti Suolinna. Nordisk udredningsserie 7/71. Nordiska rådet, Stockholm, 1971, 89-109, 89, 107.

144 Teerijoki 2007, 378.

145 Elenius 2001, 69, 76, 102, 106; Tarkiainen 1993, 287; Matti Kenttä. "Suomen kieli Ruotsin Tornionlaakson kouluissa". Tornionlaakson vuosikirja 1975. Tornionlaakson kotiseututoimikunta, Tornio, 1975, 153-166, 153; Slunga 1965, 54; Martti E. Miettinen. Pohjoisen Tornionlaakson oloista lestadiolaisen herätysliikekeen syntyaikoina. Pohjois-Pohjanmaan maakuntaliiton julkaisuja I. Oulu, 1943, 211.

146 Elenius 2001, 107, 240-241, Slunga 1965, 59; Tarkiainen 1993, 291.

147 Vähä 1993, 404; Tarkiainen 1993, 290.

148 Matti Enbuska. "Pirua ja ruotsalaisuutta vastaan - Länsipohjan kielikysymys ja vuoden 1937 ministerivierailu Tornionlaaksossa". Tornionlaakson vuosikirja 1990. Tornionlaakson kotiseututoimikunta, Tornio, 1990, 229-247, 234; Kenttä $1975,155$.

149 Rantatupa 1988, 341; Engman 2009, 106.

${ }^{150}$ Vähä 1993, 403; Rantatupa 1988, 342, 346, 409.

151 Pentti Jaako. "Kolarin kansakoulun perustaminen". Tornionlaakson vuosikirja 1986. Tornionlaakson kotiseututoimikunta, Tornio, 1986, 187-194, 189.

152 Teerijoki 2007, 360-361.

153 Heikkinen 1994, 340-341.

154 Teerijoki 2007, 488-489.

155 Teerijoki 2007, 185.

156 Suomen Suurituhtinaanmaan asetus-kokoelma 1899 N:o 3; Aki Rasilainen. "Suomen autonomia ja kysymys valtakunnanlainsäädännöstä sekä eräitä vertailuja Suomen asemaan Euroopan unionissa". Taistelu autonomiasta. Perustuslait vai itsevaltius? Edita Publishing Oy. Helsinki, 2009b, 396-421, 401-405.

${ }^{157}$ Suomen Suuriruhtinaanmaan asetus-kokoelma 1905 N:o 49; Suomen Suuriruhtinaanmaan asetuskokoelma 1910 N:0 45.

158 Päätös koskeva Suomenmaan Kenraalikuvernöörille Armossa annettuja erityisiä oikeuksia passiasioihin ja ulkomaanmatkoihin nähden. Suomen Suuriruhtinaanmaan asetuskokoelma 1916 N:o 13.

${ }_{159}$ Suomen Senaatin päätös, koskeva passiasetusten tarkempaa noudattamista. Suomen Suuriruhtinaanmaan asetuskokoelma 1917 N:o 89.

160 Heikkinen 1994, 346-349.

161 Rantatupa 1988, 367.

162 Hederyd 1993, 169, 172.

163 Svanberg 1973, 264-266; Kullervo Leinonen. "Käsivarren reitti Venäjän huollossa ensimmäisen maailmansodan aikana." Faravid 5. Pohjois-Suomen Historiallinen yhdistys. Rovaniemi, 1982, 247-333, 272; Leinonen 1982, 270.

164 Teerijoki 2007, 111; Hietaniemi 1992, 27; Osmo Jussila. "Suomen santarmihallituksen toiminnasta toisella sortokaudella." Historiallinen Aikakauskirja 3/76, 197-210,198.

165 Teerijoki 2007, 111, 535.

166 Sven Heikkilä. Gränsbygd. Blad ur mellersta Tornedalens historia. Övertorneå, 2004, 221، Rantatupa 1988, 377.

167 Teerijoki 2007, 112.

168 Teerijoki 2007, 117-118, 507; Svanberg 1973,173; Tornion Lehti 27.5.1913.

${ }^{169}$ Ilkka Teerijoki. Karungin historia. Tornion kaupunki, 2021, 191; Tornion Laakso 23.5.1913.

170 Teerijoki 2007, 507, 512, 537; Svanberg 1973, 175.

${ }^{171}$ Heikkinen 1994, 309; Juhani Kostet. "Ilmasilta Tornioon". Faravid 5. Pohjois-Suomen Historiallinen yhdistys. Rovaniemi. 1982, 215-238; Teerijoki 2007, 510-511; Hederyd 1993, 167; Teerijoki 2007, 54, 174.

172 Hederyd 1993, 169; Svanberg 1973, 220.; Leinonen 287.

173 Leinonen 1982, 274.

${ }^{174}$ Leinonen 1982, 311, 329-331.

175 Teerijoki 2007, 531-532, 534-535; Rantatupa 1988, 370.

176 Hederyd 1993, 174; Svanberg 1973, 335-336.

177 Heikkinen 1994, 335; Bergsten 2012, 8; Hederyd 1993, 167. 
178 Teerijoki 2007, 514.

179 Heikkinen 1994, 335, Teerijoki 2007, 515; Hederyd 1993, 169.

180 Jussila 2009, 95.

181 Suomen Suuriruhtinaanmaan asetuskokoelma 1917 N:o 20.

182 Jussila 2009, 98-100; Ks. Tuija Hietaniemi. Lain vartiossa. Poliisi Suomen politiikassa 1917-1948. Suomen Historiallinen Seura. Helsinki. 1992, 38- 55.

183 Teerijoki 2007, 540-544.

184 Svanberg 1973, 273.

185 Teerijoki 2007, 552-554.

186 Teerijoki 2007 554-556.

187 Teerijoki 2007, 556-558; Svanberg 1973, 273-274.

188 Teerijoki 2007, 559-562, 564; Svanberg 1973, 275-276; Leena Heikkola. Lapin historiaa. Maakuntahistoriallinen obeislukemisto. Lapin lääninhallitus - Lapin maakuntaliitto, Rovaniemi, 1982, 131-134.

189 Heikkilä 2004, 223.

${ }_{190}$ Matti Kosonen. "Rajojen vartiointi itsenäistymisen jälkeen”. Isänmaan portinvartijat. Suomen rajojen vartiointi 1918-1994. Matti Kosonen \& Juha Pohjonen. Otava, Helsinki, 1994, 11-58, 17-24; Rantatupa 1988, 386.

191 Kosonen 1994, 25-28; Heikkinen 1994, 374.

192 Svanberg 1973, 263, 278, 380-382. 